\title{
Lentiviral Vectors Mediate Efficient and Stable Gene Transfer in Adult Neural Stem Cells In Vivo
}

\author{
MARTINE GERAERTS, ${ }^{1}$ KRISTEL EGGERMONT, ${ }^{2}$ PILAR HERNANDEZ-ACOSTA, ${ }^{3}$ \\ JOSE-MANUEL GARCIA-VERDUGO,${ }^{4}$ VEERLE BAEKELANDT, ${ }^{2}$ and ZEGER DEBYSER ${ }^{1}$
}

\begin{abstract}
Modulation of adult neurogenesis may offer new therapeutic strategies for various brain disorders. In the adult mammalian brain the subventricular zone (SVZ) of the lateral ventricle is a region of continuous neurogenesis. Lentiviral vectors stably integrate into dividing and nondividing cells, in contrast to retroviral vectors, which integrate only into dividing cells. We compared their potential for gene transfer into both quiescent and slowly dividing stem cells as well as into more rapidly dividing progenitor cells. In contrast to retroviral vectors, stereotactic injection of lentiviral vectors into the SVZ of adult mice resulted in efficient and long-term marker gene expression in cells with characteristics of both immature type $B$ cells and migrating precursor cells. After migration along the rostral migratory stream and differentiation, the number of enhanced green fluorescent protein (eGFP)-expressing granular and periglomerular interneurons increased over time in the ipsilateral olfactory bulb. Moreover, the number of eGFP-labeled neuronal progenitor cells in the SVZ increased over time. By intraventricular injection of lentiviral vectors we could restrict gene transfer to ependymal cells and type B astroglial-like stem cells. In conclusion, lentiviral vectors surpass retroviral vectors in efficient long-term in vivo marking of subventricular zone stem cells for basic research and therapeutic applications.
\end{abstract}

\section{OVERVIEW SUMMARY}

There is a need for technologies to label the neural stem cells that are present in the adult mammalian brain. The marking techniques used today, based on bromodeoxyuridine incorporation and retroviral vector gene marking, label only dividing cells at the time of administration. Here we demonstrate the ability of lentiviral vectors to transfer genes into subventricular zone (SVZ) stem cells. A single stereotactic injection of lentiviral vectors into the $S V Z$ resulted in long-term marker gene expression in both type $B$ stem cells and dividing progenitor cells. Because SVZ progenitor cells migrate along the rostral migratory stream, a clear increase in marker gene expression was observed in the olfactory bulb over time. Lentiviral vectors can thus be used for long-term follow-up of migrating and differentiating progenitor cells.

\section{INTRODUCTION}

$\mathbf{E}$ ARLY EVIDENCE of adult neurogenesis in rodent brain was obtained by Altman, Kaplan, and coworkers (Altman and Das, 1965; Altman, 1969; Kaplan and Hinds, 1977), employing tritiated thymidine mitotic labeling and electron microscopy. In later studies with the thymidine analog 5-bromo2'-deoxyuridine (BrdU) (Cameron et al., 1993; Lois and Alvarez-Buylla, 1994; Lois et al., 1996), retroviral vector-mediated cell marking (Morshead and van der Kooy, 1992; Luskin, 1993) and clonal expansion/differentiation in cell culture (Reynolds and Weiss, 1992; Palmer et al., 1997) unequivocally demonstrated the presence of actively dividing neural stem cells (NSCs) in restricted areas of the adult brain of mammals, including humans. True NSCs have an unlimited self-renewal capacity and are multipotent. They can differentiate into neurons, astrocytes, and oligodendrocytes (Reynolds and Weiss, 1992;

${ }^{1}$ Laboratory for Molecular Virology and Gene Therapy, Katholieke Universiteit Leuven and IRC KULAK (Interdisciplinary Research Center, Katholieke Universiteit Leuven-Campus Kortrijk), Leuven, 3000, Belgium.

${ }^{2}$ Laboratory for Neurobiology and Gene Therapy, Katholieke Universiteit Leuven, Leuven, 3000, Belgium.

${ }^{3}$ Centro de Investigación Príncipe Felipe, Valencia 46013, Spain.

${ }^{4}$ Institut Cavanilles de Biodiversitat i Biologia Evolutiva, Universitat de València, Burjassot 46100, Valencia, Spain. 
Johe et al., 1996), depending both on intracellular signals and on local environmental cues referred to as the stem cell niche (Alvarez-Buylla and Lim, 2004).

In the adult brain, two places of continuous neurogenesis are described: the subventricular zone (SVZ) of the lateral ventricles and the subgranular layer of the dentate gyrus (Ming and Song, 2005). In the dentate gyrus, neural precursor cells migrate into the molecular layer and give rise to mature, electrically active granular cells, sending axons to the CA3 region and projecting dendrites to the outer molecular layer (Kempermann et al., 2004). To what extent these newly generated neurons contribute to the function of the hippocampus is not completely known, but studies show their importance in the formation of new memories (Prickaerts et al., 2004). Neural precursor cells from the second neurogenic region, the SVZ, migrate tangentially in chains to the olfactory bulb (OB) through tubular structures formed by specialized astrocytes, forming a migratory pathway called the rostral migratory stream (RMS). On arrival in the olfactory bulb progenitor cells dislodge from their chains and migrate radially into the overlying granular and periglomerular cell layers, where they differentiate into local interneurons (Alvarez-Buylla and Garcia-Verdugo, 2002). The total number of cells, however, is balanced by death of newly formed and possibly older neurons (Biebl et al., 2000; Petreanu and Alvarez-Buylla, 2002). Because newly formed neurons respond to olfactory stimuli, it is thought that continuous addition of neurons in the bulb is involved in olfactory memory formation (Saghatelyan et al., 2003). Past characterization of the SVZ structure revealed the presence of three different dividing cell types: slowly proliferating astroglial-like cells (type B cells), which give rise to rapidly proliferating, transit-amplifying progenitors (type $\mathrm{C}$ cells), which in turn give rise to migrating neuroblasts (type A cells). Moreover, it was demonstrated that multipotent neural stem cells can be isolated from the whole SVZ-RMS-OB system and that progenitors from granular or periglomerular neurons are present at different locations and express different markers (Gritti et al., 2002; Hack et al., 2005). Therefore the idea of a simple lineage differentiation (type $\mathrm{B} \rightarrow$ type $\mathrm{C} \rightarrow$ type $\mathrm{A}$ ) should be studied in more detail (Guillemot and Parras, 2005). Neural progenitors have also been detected in low numbers in other brain regions, but their functional relevance is yet unknown.

Although various growth factors as well as environmental factors (stress, exercise, and enrichment), hormones, neurotransmitters, and psychotropic agents have all been reported to mediate neurogenesis, to date we lack a unifying theory with functional relevance (Parent, 2003; Taupin, 2005). Interestingly, evidence is accumulating that pathological conditions may stimulate the neurogenic potential of the adult brain. Brain damage due to excitotoxic or mechanical lesions, focal or global ischemic injury, and chemoconvulsant-induced seizure activity have all been reported to increase the population of neural precursor cells in both the subgranular layer and the SVZ (Parent, 2003; Taupin, 2005). In models of neurodegenerative diseases such as Parkinson's disease and Alzheimer's disease, it is not clear whether neurogenesis is up- or downregulated (Fallon et al., 2000; Lie et al., 2002; Curtis et al., 2003; Zhao et al., 2003; Jin et al., 2004). Newly born neurons have been shown to integrate into existing neural networks, although the functional significance awaits elucidation.
More studies are required to increase our understanding of the regulation of neurogenesis in healthy and diseased adult mammalian brain. Technology that offers genetic manipulation of endogenous NSCs and results in controlled regulation of proliferation, migration, and differentiation of progenitors may lead to new therapeutic strategies for CNS disease including neurodegeneration. Because lentiviral vectors, in contrast to retroviral vectors, are known to transduce both dividing and nondividing cells, we wanted to evaluate lentiviral vector-mediated gene transfer into adult NSCs in vivo. Our study clearly demonstrates that lentiviral vectors can be used for efficient and long-term in vivo marking of rodent adult NSCs in the SVZ, allowing tracking of neural progenitor cells during proliferation, migration, and differentiation. While our work was ongoing, Consiglio et al. reported on efficient gene marking of neuronal precursor cells in the SVZ, using lentiviral vectors (Consiglio et al., 2004). Our detailed in vivo analysis provides further evidence of gene marking of type B cells, using lentiviral vectors.

\section{MATERIALS AND METHODS}

\section{Lentiviral vector production and concentration}

High-titer human immunodeficiency virus type 1 (HIV-1)derived lentiviral vector particles, pseudotyped with the envelope of vesicular stomatitis virus (VSV-G), were produced by transfecting 293T cells with a second-generation packaging plasmid lacking vif, vpr, vpu, and nef genes (pCMV $\Delta$ R8.91), a plasmid encoding the envelope of vesicular stomatitis virus (pMDG), and a $\mathrm{pHR}^{\prime}$-derived transfer plasmid (pCH-eGFPWS) encoding enhanced green fluorescent protein (eGFP) as a reporter gene. This three-plasmid transient transfection system was originally described by Naldini et al. (1996) and subsequently modified and upscaled (Geraerts et al., 2005). Briefly, after triple transient transfection of 293T cells seeded in 10-tray Cell Factories (CFs; Nunc, Roskilde, Denmark) in OptiMEM serum-free medium (GIBCO-BRL; Invitrogen, Merelbeke, Belgium), 2 liters of cell culture medium was harvested, purified, and concentrated to a volume of $30 \mathrm{ml}$ by tangential flow filtration (TFF) with a benchtop TFF apparatus (Minim; Pall, Dreieich, Germany) equipped with a $100-\mathrm{kDa}$ Omega screen cassette, according to the manufacturer's protocol. To increase vector titers even more after TFF for gene transfer into rodent brain, an extra ultracentrifugation step for $2 \mathrm{hr}$ at $4^{\circ} \mathrm{C}$ in a swinging-bucket rotor (SW55.1; Beckman Coulter, Fullerton, CA) at $76,000 \times g$ was performed. The pellet was resolved in $1 \mathrm{ml}$ of phosphate-buffered saline (PBS) and stored at $-80^{\circ} \mathrm{C}$ until use. The lentiviral vector contains the self-inactivating (SIN) deletion for biosafety reasons (Zufferey et al., 1998) and the central polypurine tract (cPPT) (Manganini et al., 2002; Van Maele et al., 2003) to increase nuclear import. eGFP expression was driven by the constitutive immediate-early enhancer/promoter of human cytomegalovirus (CMV) and was enhanced by the woodchuck posttranscriptional regulatory element (Zufferey et al., 1999). We previously obtained stable, long-term transduction of neurons in rodent brain, using the same $\mathrm{CH}$-eGFP-WS lentiviral vector (Baekelandt et al., 2003). 


\section{Retroviral vector production and concentration}

Retroviral vector particles were produced as described for lentiviral vectors. For triple transient transfection the following plasmids were used: pMDG as envelope plasmid, CMVintron as packaging plasmid (kind gift of F.L. Cosset, INSERM, Lyon, France), and LNC-GFP as transfer plasmid (kind gift of G. Towers, University College London, London, UK). The retroviral vector construct used has been described by Towers and colleagues (2002).

\section{Viral vector titer determination}

Lentiviral vector stocks were normalized by their HIV-1 p24 antigen content (HIV-1 p24 enzyme-linked immunosorbent assay [ELISA] kit; PerkinElmer, Milan, Italy). For our vector preparations a p24 concentration of $10^{6}-10^{7} \mathrm{pg}$ of p24 per milliliter is routinely obtained. Functional titers, determined by fluorescence-activated cell-sorting (FACS) analysis of eGFP expression after limiting dilution in Chinese hamster ovary $(\mathrm{CHO})$ cells, amount to $10^{9}-10^{10}$ transducing units (TU)/ml.

To compare lentiviral with retroviral vector titers, genomic RNA contents were measured by real-time quantitative reverse transcription (RT)-PCR as described (Martin-Rendon et al., 2002). After RNA extractions of concentrated vector preparations (RNAqueous-Micro kit; Ambion, Cambridgeshire, UK), RNA was amplified with a TaqMan One-Step RT-PCR master mix reagents kit (Applied Biosystems, Lennik, Belgium) with primers and probe located in the eGFP transgene, present in both vector constructs. Forward and reverse primers used were, respectively, as follows: 5' - GGAGCGCACGATCTTCTTCA-3' and 5'-AGGGTGTCGCCCTCGAA-3'. The TaqMan probe used was 5'-FAM-CTACAAGACCCGCGCCGAGGTG-TAMRA-3'. RNA contents for both vectors ranged from $10^{9}$ to $10^{11}$ RNA copies/ml.

\section{Stereotactic surgery}

Animal experiments were approved by the bioethics committee of Katholieke Universiteit Leuven (Leuven, Belgium). Female adult C57BL/6 mice were housed under a 14 hr light:10 hr dark cycle with free access to food and water. For surgery, 3-week-old and 8- to 9-week-old animals were anesthetized intraperitoneally with ketamine (Ketamine 1000, $75 \mathrm{mg} / \mathrm{kg}$; CEVA Santé Animale, Libourne, France) and medetomidin (Domitor, $1 \mathrm{mg} / \mathrm{kg}$; Orion Pharma, Espoo, Finland) and positioned in a stereotactic head frame (Stoelting, Wood Dale, IL) for stereotactic injection into the SVZ and the lateral ventricle (LV). The skull was exposed by a small midline incision and a hole was drilled into the skull in the appropriate location, using bregma as the reference point. Stereotactic coordinates starting from the dura were as follows: SVZ-anteroposterior, 0.6 $\mathrm{mm}$; mediolateral, $1.6 \mathrm{~mm}$; dorsoventral, 3-2 $\mathrm{mm}$; and LVanteroposterior, $-0.2 \mathrm{~mm}$; mediolateral, $1 \mathrm{~mm}$; dorsoventral, 1.8 mm. Using a 30-gauge Hamilton syringe (VWR International, Haasrode, Belgium), 1 or $5 \mu$ l of highly concentrated vector, supplemented with Polybrene $(4 \mu \mathrm{g} / \mathrm{ml})$, was injected at a rate of $0.25 \mu \mathrm{l} / \mathrm{min}$ into the SVZ or LV, respectively. After injection, the needle was left in place for an additional $5 \mathrm{~min}$ and anesthesia was reversed with atipamezol (Antisedan, $0.5 \mathrm{mg} / \mathrm{kg}$; Orion Pharma), administered intraperitoneally. To label divid- ing cells in the brain, 5-bromo-2'-deoxyuridine (BrdU, 50 $\mathrm{mg} / \mathrm{kg}$; Sigma-Aldrich, Bornem, Belgium) was injected intraperitoneally into operated animals once per day for five consecutive days before perfusion or 2 weeks before perfusion for analysis of cell migration and differentiation.

\section{Tissue processing and immunohistochemistry}

After stereotactic injection, animals were killed at various time points with an intraperitoneal overdose of pentobarbital (Nembutal; CEVA Santé Animale) and transcardially perfused with $4 \%$ (w/v) paraformaldehyde (PFA) in PBS. Brains were removed and postfixed overnight in $4 \%$ PFA. Serial $50-\mu \mathrm{m}$ coronal and sagittal sections were made with a microtome (Vibratome, St. Louis, MO). For eGFP immunohistochemistry, free-floating sections were treated with $3 \%(\mathrm{v} / \mathrm{v}) \mathrm{H}_{2} \mathrm{O}_{2}$ in PBS for $10 \mathrm{~min}$ to remove endogenous peroxidase activity, washed, and incubated overnight with rabbit anti-eGFP primary antibody (diluted 1:10,000, made in-house by immunization with purified eGFP [Clontech, Palo Alto, CA] [Baekelandt et al., $2003]$ in PBS-10\% swine serum $[\mathrm{v} / \mathrm{v}]-0.1 \%$ Triton $\mathrm{X}-100$ $[\mathrm{v} / \mathrm{v}]-0.02 \%[\mathrm{w} / \mathrm{v}]$ sodium azide). The next day, the primary antibody was removed; the sections were washed and incubated for 30 min with biotinylated swine anti-rabbit antibody (diluted 1:300; Dako, Heverlee, Belgium) diluted in PBS-0.1\% (v/v) Triton X-100. Afterward, sections were washed with PBS-0.1\% Triton X-100 (v/v) and incubated for 30 min with StreptABComplex-horseradish peroxidase (HRP) (Dako) in PBS- $0.1 \%$ (v/v) Triton. The biotin-streptavidin-peroxidase complex was visualized with 3,3'-diaminobenzidine $(0.4 \mathrm{mg} / \mathrm{ml}$; SigmaAldrich) and $\mathrm{H}_{2} \mathrm{O}_{2}(0.03 \%$, v/v). Before analysis by light microscopy, sections were mounted on glass slides, dehydrated, and coverslipped with DPX mountant (Fluka; Sigma-Aldrich).

Before incubation with anti-BrdU antibody, pretreatment with $2 \mathrm{~N} \mathrm{HCl}$ for $30 \mathrm{~min}$ at $37^{\circ} \mathrm{C}$ followed by incubation with $0.1 \mathrm{M}$ boric acid for $25 \mathrm{~min}$ at room temperature was necessary to denature the DNA. Double and triple immunofluorescence stainings were done overnight at room temperature in PBS-10\% horse serum (v/v)-0.1\% Triton (v/v) with the following antibodies: rat anti-BrdU (diluted 1:400; Accu-Specs/ Labconsult, Brussels, Belgium), goat anti-doublecortin for immature neurons (diluted 1:200; Santa Cruz Biotechnology, Heidelberg, Germany), mouse anti-PSA-NCAM (polysialic acid form of neural cell adhesion molecule) for migrating neuroblasts (diluted 1:400; Chemicon International/Biognost, Heule, Belgium), mouse anti-neuronal nuclear antigen (NeuN) for mature neurons (diluted 1:200; Chemicon International), mouse anti-glial fibrillary acidic protein (GFAP) for astroglial cells and type B stem cells (diluted 1:200; BD Biosciences Pharmingen, Erembodegem, Belgium), rabbit $\mathrm{S}-100 \beta$ for mature glial cells (diluted 1:2500; Swant, Bellinzona, Switzerland), and rabbit anti-eGFP (diluted 1:10,000; made in-house) or chicken antieGFP (diluted 1:1000; Aves Labs, Tigard, OR). The next day, sections were incubated with one of the following fluorescently labeled secondary antibodies at room temperature for $2 \mathrm{hr}$ : donkey anti-rabbit-Alexa 488 (diluted 1:200; Molecular Probes, Leiden, The Netherlands); donkey anti-mouse-Alexa 555 (diluted 1:200; Molecular Probes); donkey anti-mouse-rhodamine red-X (IgM) (diluted 1:200; Dianova/Jackson ImmunoResearch, Hamburg, Germany); donkey anti-goat-Alexa 555 (di- 
luted 1:200; Molecular Probes); donkey anti-rat-Cy5 (diluted 1:200; Dianova/Jackson ImmunoResearch); donkey anti-chickenfluorescein isothiocyanate (FITC) (diluted 1:200; Dianova/ Jackson ImmunoResearch), and donkey anti-rabbit-Alexa 647 (diluted 1:200; Molecular Probes). All secondary antibodies were adsorbed against several species to reduce crossreactivity. Sections were mounted on glass slides, coverslipped with polyvinyl alcohol/1,4-diazabicyclo-[2.2.2]octane (PVADABCO) (Fluka; Sigma-Aldrich), and analyzed by laserscanning confocal microscopy (ConfoCor 2; Carl Zeiss, Oberkochen, Germany).

\section{Electron microscopy}

For electron microscopy analysis, brain sections were processed as described previously after 3,3'-diaminobenzidine staining with the anti-eGFP antibody on $50-\mu \mathrm{m}$ Vibratome slices (Herrera et al., 1999). Briefly, the sections were postfixed in $2 \%$ osmium for $1.5 \mathrm{hr}$, incubated in $2 \%$ uranyl acetate for 2 hr, dehydrated, and embedded in Araldite (Durcupan ACM Fluka; Fluka BioChemika, Ronkonkoma, NY). To study the overall organization of the SVZ and the striatum, we cut 1.5$\mu \mathrm{m}$ semithin sections with a diamond knife and stained them with $1 \%$ toluidine blue. Ultrathin $(0.05 \mu \mathrm{m})$ sections were cut with a diamond knife, stained with lead citrate, and examined with a JEOL (Tokyo, Japan) electron microscope.

\section{Double-labeled cell counting in the SVZ}

To analyze the transduction efficiency of lentiviral vectors in proliferating cells in the SVZ, colabeling for eGFP and doublecortin was performed as described previously. Double-labeled cells were identified by laser-scanning confocal microscopy (ConfoCor 2). For each animal a total number of about 1000 doublecortin-positive cells was counted in 7 sections at $300-\mu \mathrm{m}$ intervals, taken from the dorsolateral area at the top of the lateral ventricle and the subventricular region next to the transduced brain area. Doublecortin-positive cells located in the ventral area of the subventricular region/lateral ventricle were not taken into account, because vector transduction did not reach into this area. eGFP- and doublecortin-positive cells were identified by orthogonal reconstructions from $z$ series taken with a $\times 40$ objective and are presented as a percentage of the total number of doublecortin-positive cells.

\section{Stereological estimation of total number of eGFP cells in the $O B$}

A random-sampling stereological counting tool, the optical fractionator method (West et al., 1991), was used to count total numbers of eGFP cells in the OB. For each animal seven sections at $300-\mu \mathrm{m}$ intervals throughout the OB were used. First, the area of interest was anatomically defined. A regular grid was superimposed over this area and a three-dimensional counting frame of fixed size was placed within each square of the grid. By this setup, all cells were equally likely to be sampled. Cells within the counting frames were counted and an estimation of the total number of cells in the area of interest was obtained with Stereoinvestigator software (version 5; MicroBrightField, Magdeburg, Germany) and a Leica DMR Biopoint 2 microscope (Leica Microsystems, Wetzlar, Germany).

\section{RESULTS}

\section{Lentiviral vectors transduce NSCs and migrating neuroblasts whereas retroviral vectors transduce mainly migrating neuroblasts after injection into the SVZ}

To investigate the potential for lentiviral vector-mediated transduction of adult neural stem and progenitor cells in mouse brain, we injected $1.4 \times 10^{6} \mathrm{TU}\left(1.4 \times 10^{8} \mathrm{RNA}\right.$ copies $)$ of an HIV-1-derived lentiviral vector pseudotyped with the vesicular stomatitis virus envelope (VSV-G) into the right SVZ of 24 female C57BL/6 mice, 8-9 weeks of age (Fig. 1B). Injection of
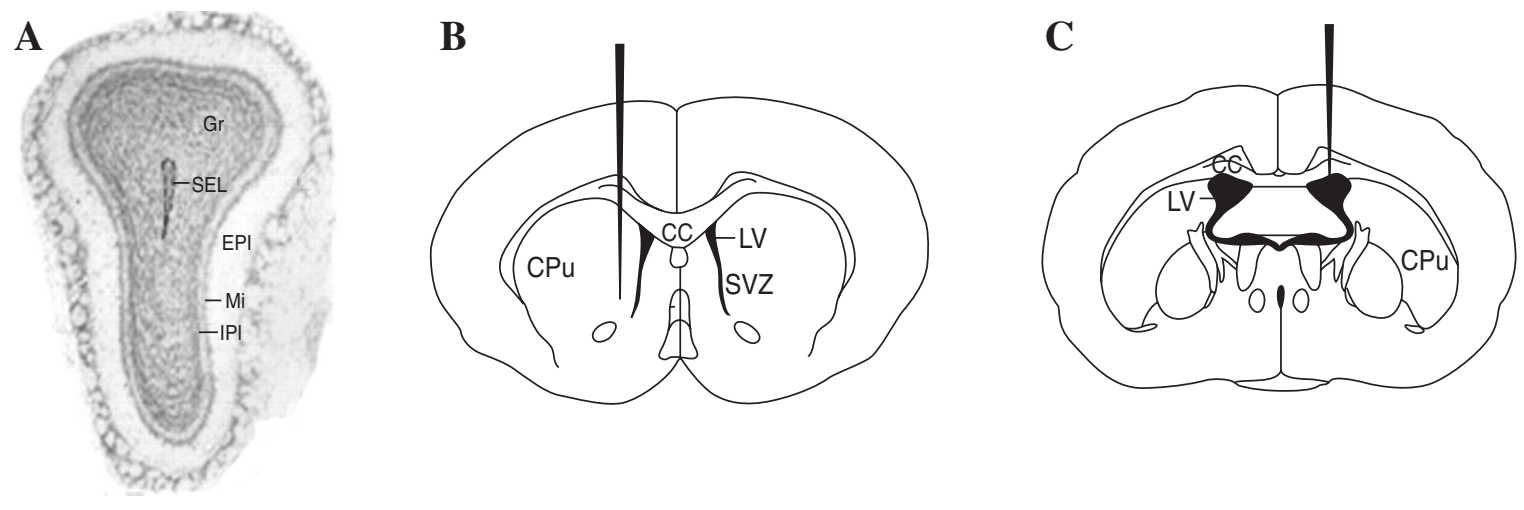

FIG. 1. Structure of the olfactory bulb and overview of stereotactic coordinates. Immature neurons originating from the subventricular zone (SVZ) of the lateral ventricles (LV) migrate through the rostral migratory stream into the subependymal layer (SEL) of the olfactory bulb. There they mature mainly into local interneurons of the granular layer (Gr) and periglomerular layer (Gl). The external plexiform layer (EPl), the mitral cell layer (Mi), and the internal plexiform layer (IPl) separate the Gl from the Gr (A). Gene transfer into SVZ neuronal stem cells was accomplished by stereotactic delivery of lentiviral vectors encoding enhanced green fluorescent protein (eGFP) in the SVZ (B) at the following coordinates, starting from the dura: anteroposterior, $0.6 \mathrm{~mm}$; mediolateral, $1.6 \mathrm{~mm}$; dorsoventral, 3-2 mm, or inside the LV (C) at the following: anteroposterior, $-0.2 \mathrm{~mm}$; mediolateral, $1 \mathrm{~mm}$; dorsoventral, $1.8 \mathrm{~mm}$. cc, corpus callosum; $\mathrm{CPu}$, caudate putamen. 


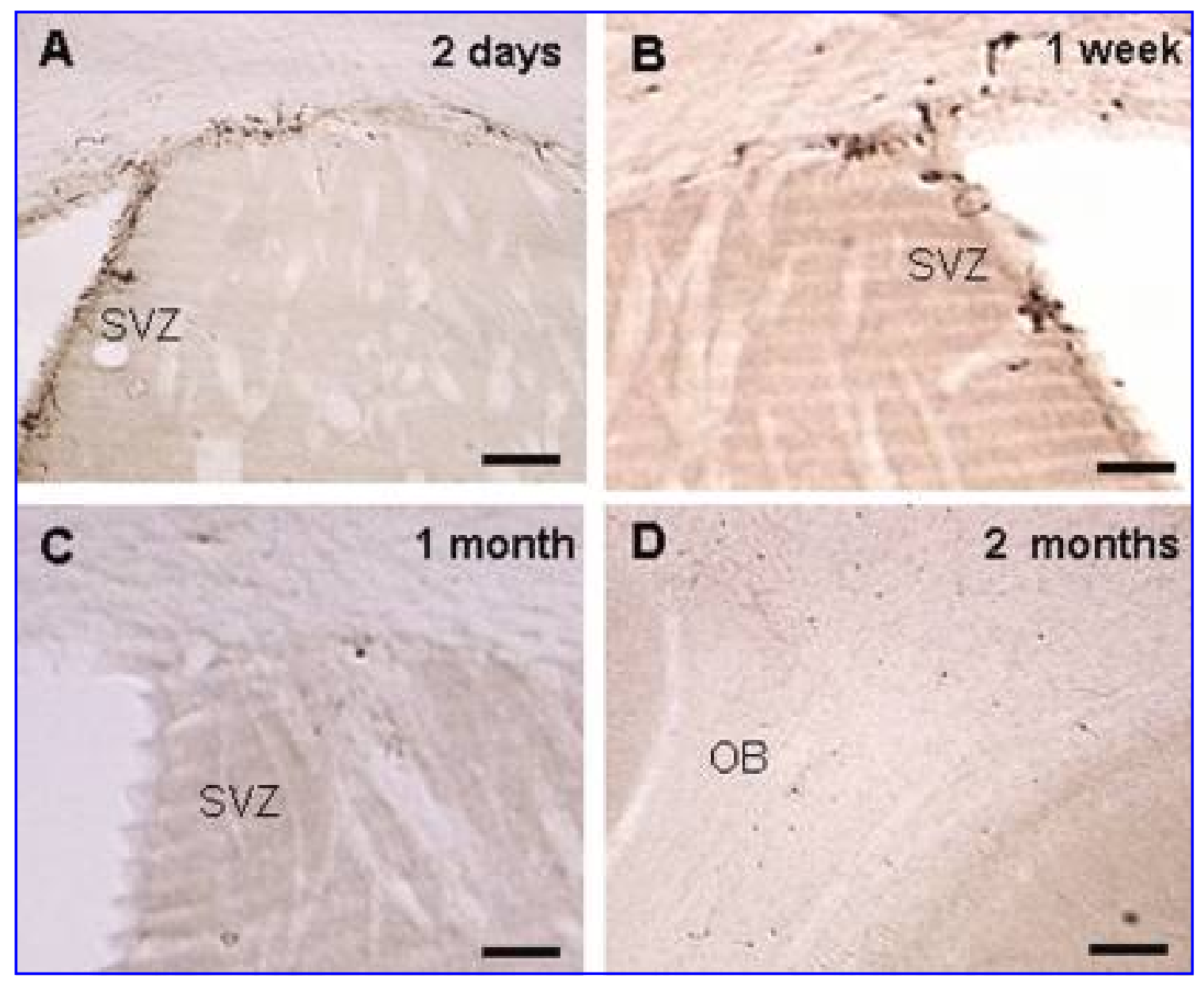

FIG. 2. Marking of dividing cells in the SVZ-RMS-OB pathway by injection of retroviral vectors into the SVZ. High-titer retroviral vectors encoding eGFP were injected into the SVZ of C57BL/6 mice and analyzed 2 days, 1 week, 2 weeks, 1 month, and 2 months later. (A) eGFP expression was detected in the SVZ and the RMS 2 days after injection. (B) The number of marked cells started to decline from 1 week until 1 month $(\mathbf{C})$ after injection into the SVZ, whereas in the OB eGFP-positive maturing neurons started to appear from 1 week after injection and were still present 2 months after injection (D). Scale bars: $100 \mu \mathrm{m}$. $\mathrm{OB}$, olfactory bulb; SVZ, subventricular zone.

this vector into rodent brain is known to result in stable longterm gene expression in postmitotic neurons and glia around the injection site in the absence of retrograde transport (Baekelandt et al., 2002). At various time points after stereotactic injection (2 days, 1 week, 2 weeks, 1 month, 2 months, and 7 months) four animals were killed and eGFP expression in the SVZ-RMS-OB migratory pathway was verified by immunohistochemistry. During the five consecutive days before perfusion, animals were injected with $\mathrm{BrdU}(50 \mathrm{mg} / \mathrm{kg})$ to label dividing cells in the brain. In a parallel experiment, retroviral vector $\left(2.6 \times 10^{8}\right.$ RNA copies) encoding eGFP and pseudotyped with VSV-G was also injected into the SVZ of 15 female C57BL/6 mice, 8-9 weeks of age. The animals were killed 2 days, 1 week, 2 weeks, 1 month, and 2 months later. Retroviral vectors are used frequently (Morshead and van der Kooy, 1992; Luskin, 1993; Petreanu and Alvarez-Buylla, 2002) to label dividing and migrating cells (mainly type A neuroblasts) in the brain. Therefore, retroviral vector-injected animals served as a control for cell migration, differentiation, and survival and were compared with lentiviral vector-injected animals for transduction of adult NSCs.
Two days after injection of retroviral vector into the SVZ, eGFP expression was detected in the SVZ and RMS (Fig. 2A). However, from 1 week on after injection the number of $\mathrm{eGFP}^{+}$ cells in the SVZ started to decrease (Fig. 2B). At the latest time points evaluated ( 1 and 2 months), few eGFP-positive cells remained in the SVZ (Fig. 2C). From 2 days after injection a few eGFP-positive cells were detected in the subependymal layer from the $\mathrm{OB}$, implying migration of transduced cells or their progeny. After 1 week the eGFP-positive cells were present mainly in the granular layer and displayed morphological characteristics of mature granular interneurons. The number of eGFP-positive cells in the OB was low and remained constant between 1 week and 2 months (Fig. 2D). Our data are in accordance with previously described reports wherein neuroblast migration from the SVZ to the OB was shown to take 2 to 7 days and wherein retroviral vectors were shown to label preferentially migrating cells (Luskin, 1993; Petreanu and AlvarezBuylla, 2002).

Next, we injected HIV-1-derived lentiviral vectors into the SVZ. In these mice, eGFP expression in the transduced brain 


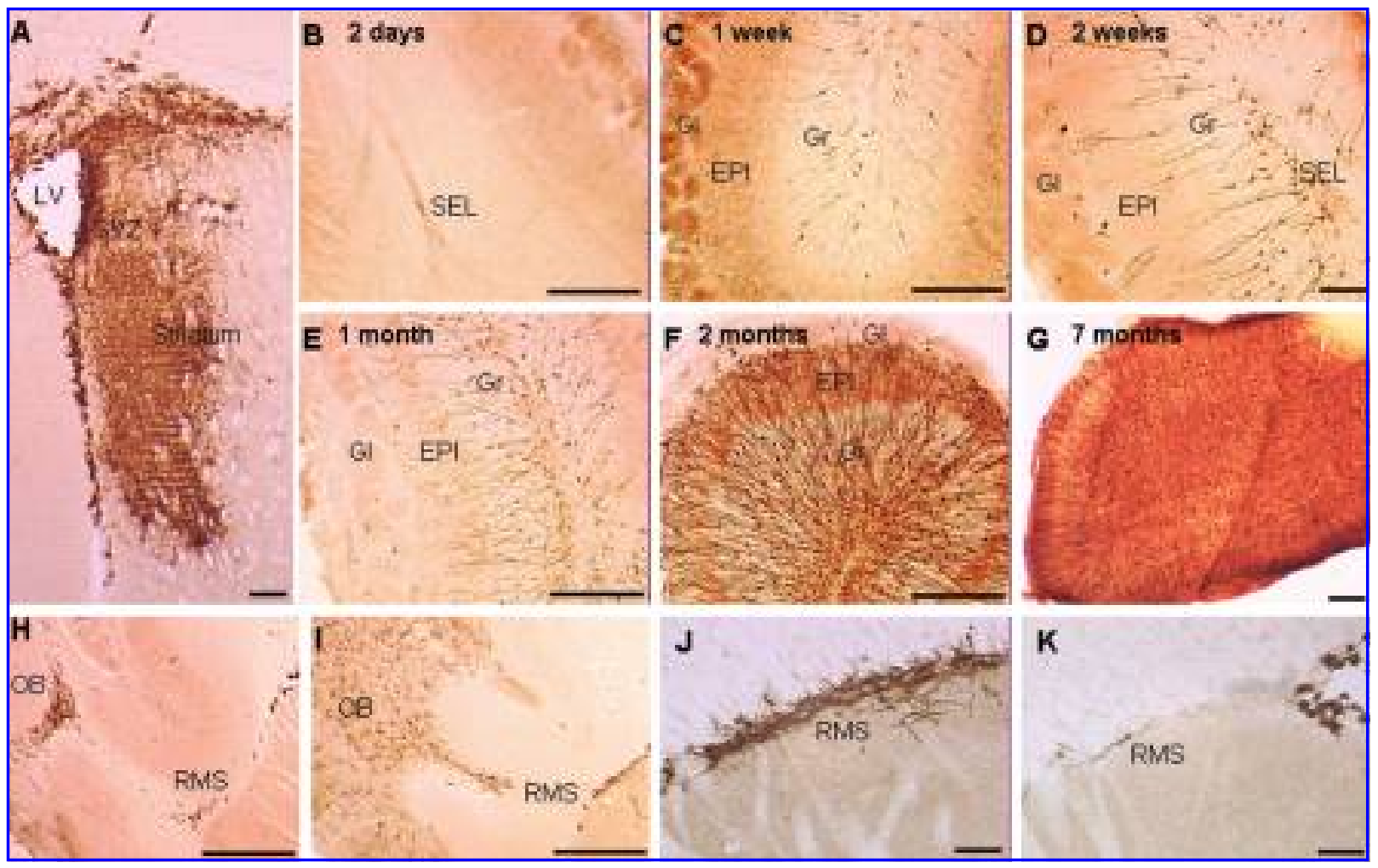

FIG. 3. Neural stem cell marking of the LV-RMS-OB pathway by injection of lentiviral vectors in the SVZ. High-titer lentiviral vectors encoding eGFP were injected into the right SVZ of C57BL/6 mice. EGFP expression was analyzed by immunohistochemistry 2 days, 1 week, 2 weeks, 1 month, 2 months, and 7 months after injection. (A) In the SVZ eGFP-positive cells were present around the needle track until 7 months. (B) Marker gene expression was detected in the ipsilateral SEL of the OB from 2 days on after injection. (C) From 1 week on after injection, maturing eGFP-positive cells were also detected in the granular layer and to a lesser extent in the glomerular layer of the OB. (D-G) Over time, marker gene expression accumulated in the ipsilateral OB in the various cell layers. (H) BrdU staining after pulse labeling of dividing cells 5 days before perfusion shows labeling in the RMS and SEL, whereas (I) a single lentiviral vector injection into the SVZ shows continuous labeling of migrating cells in the RMS and OB at all time points evaluated. ( $\mathbf{J}$ and $\mathbf{K}$ ) Detailed pictures of eGFP-expressing migrating cells in the RMS 2 months after injection, illustrating the longitudinal profile of eGFP-positive migrating cells with the typical morphology of a small elongated cell body and a long leading process pointing toward the OB. (J) after injection into the SVZ; $\mathbf{K}$, after injection into the LV) (A-F) coronal sections; (G-K) sagittal sections. Scale bars: (A-C, E-I) $100 \mu \mathrm{m}$; (D, J, and K) $25 \mu \mathrm{m}$. EPl, external plexiform layer; Gl, glomerular layer; Gr, granular layer; LV, lateral ventricle; OB, olfactory bulb; RMS, rostral migratory stream; SEL, subependymal layer.

area and the SVZ was stable for at least 7 months (Fig. 3A). Because neither the VSV-G envelope nor the CMV promoter provided neural precursor cell (NPC) specificity, injection at the coordinates used resulted in transduction of mature striatal neurons as well. Two days after injection a few eGFP-positive cells were already detected in the subependymal layer of the ipsilateral OB (Fig. 3B). From 1 week on, eGFP-positive cells started to appear in the granular layer and a few cells were detected in the glomerular layer (Fig. 3C). The number of eGFPpositive cells in the $\mathrm{OB}$ clearly increased over time until 7 months after injection (Fig. 3B-G). In addition, eGFP-positive cells were detected in the RMS and subependymal layer at all time points evaluated (Fig. 3I-K). The persistent eGFP expression in the SVZ-RMS-OB pathway after a single lentiviral vector delivery (Fig. 3I) compared with the BrdU labeling (Fig. 3H) of cells after pulse labeling of dividing cells for five consecutive days shows the presence of migrating cells in the RMS and OB. Sagittal sections from the RMS show a longitu- dinal profile of the neuroblasts with an elongated cell body and a leading process usually pointing toward the bulb (Fig. 3K) (Lois and Alvarez-Buylla, 1994). eGFP-positive cells were also detected in the ipsilateral accessory olfactory bulb, but no eGFP-positive cells were found in the contralateral OB. Most marked cells in the OB were granular interneurons with dendritic arborization into the external plexiform layer. However, eGFP-positive cells were also present in the glomerular layer, the internal plexiform layer, and/or the mitral cell layer (for detailed pictures, see Fig. 6). Reportedly, only a small percentage of migrating SVZ cells integrate into these layers (Luskin, 1993; Yamada et al., 2004).

\section{Identification of eGFP-expressing cells in the SVZ and $O B$}

To identify cell types in the SVZ and OB that are labeled with eGFP, we performed double or triple immunofluorescence 


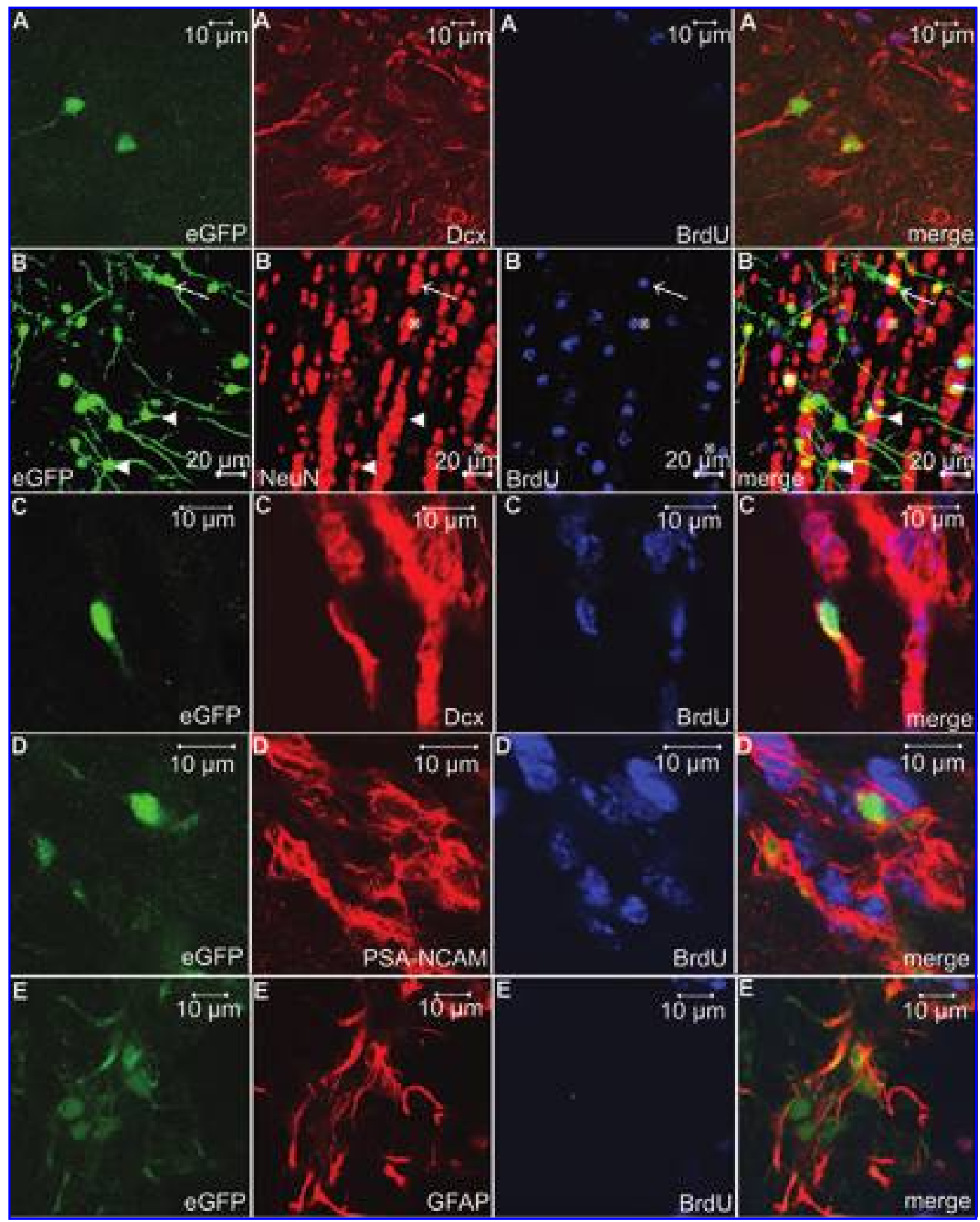

FIG. 4. Characterization of eGFP-positive cells in the OB and SVZ after delivery of lentiviral vectors into the SVZ. (A-E) Triple immunofluorescence staining with anti-eGFP (green), anti-BrdU (blue), and anti-dcx, anti-NeuN, anti-GFAP, or anti-PSANCAM (red) antibodies was followed by $z$-stack confocal analysis of coronal sections of the OB (A and B) or the SVZ (C-E). In the SEL, marked cells costain with dcx, a marker for neural progenitor cells (A), whereas in the granular layer eGFP-expressing cells costain with NeuN, a marker for mature neurons [arrowheads in (B)]. Two weeks after pulse labeling of dividing cells with BrdU, newly generated, matured eGFP-positive neurons were detected in the OB as shown by eGFPNeuN-BrdU costaining [arrow in (B)]. Nonlabeled newly generated neurons (BrdU-NeuN positive) were also detected in the $\mathrm{OB}$ [asterisk in (B)]. In the SVZ, gene transfer into immature neural stem cells (type B cells) and proliferating and migrating neuroblasts (type A cells) was made evident by costaining with GFAP (E) and dcx (C) or PSA-NCAM (D), respectively. At all time points evaluated, cells positive for GFAP and eGFP; dex, eGFP, and BrdU; and PSA-NCAM, eGFP, and BrdU were detected in the SVZ and RMS. 
costainings with various antibodies and confocal analysis. eGFP-marked cells in or near the subependymal layer of the OB costained with doublecortin (dcx), a marker for maturing neurons (Fig. 4A) (Francis et al., 1999). The majority of eGFPpositive cells in the $\mathrm{OB}$ were mature neurons as evidenced by double staining with anti-NeuN antibody (arrowheads in Fig. 4B). Moreover, these mature eGFP-expressing granular interneurons were newly generated because some cells also colabeled with BrdU after S-phase labeling of cells for five consecutive days (started 1 month after stereotaxy), 2 weeks before perfusion. The protocol labels the proliferating cells in the SVZ at the time of BrdU administration; 2 weeks later, some of the labeled cells will have migrated to the $\mathrm{OB}$ and matured into granular neurons. Figure 4B (arrow) shows eGFP-BrdU-NeuN triple-positive cells. Many cells stain positive for $\mathrm{NeuN}$ and BrdU but are negative for eGFP (Fig. 4B). These neurons are derived from proliferating, migrating, and differentiating cells that have not been transduced with the lentiviral vector.

Whereas retroviral vector-labeled cells were only transiently present in the SVZ, lentiviral vector-labeled cells remained present in the RMS and the number of transduced cells in the OB increased over time (until 7 months). This suggests that lentiviral vectors may be more efficient in gene transfer to NSCs in the SVZ. To determine whether eGFP-positive cells in the SVZ are
A

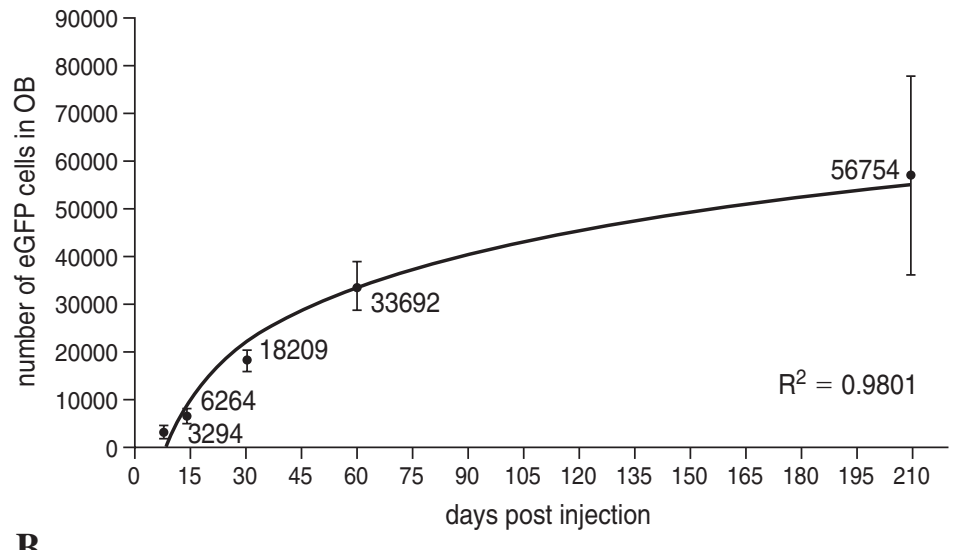

B

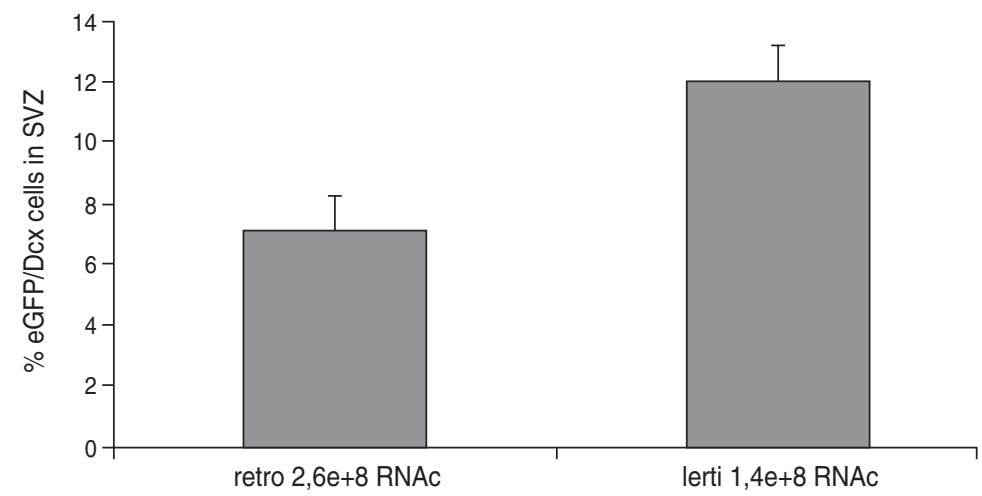

\section{C}

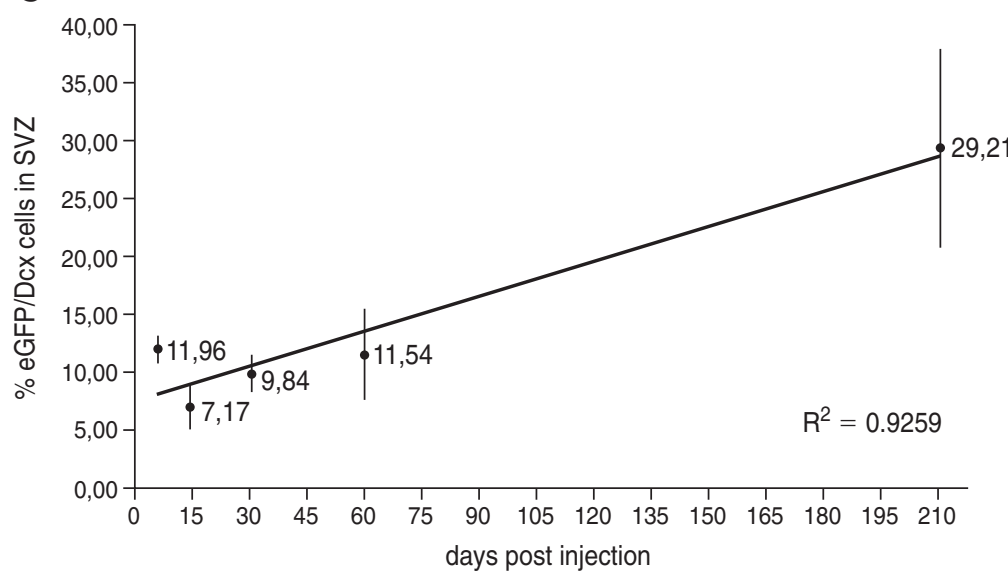

FIG. 5. Quantification of transduction efficiency in the SVZ and OB. (A) Stereological quantification of the number of eGFP-positive cells in the $\mathrm{OB}$, with the optical fractionator method, shows a semilogarithmic increase over time with a correlation coefficient of $r^{2}=0.98$. (B) eGFP-dcx double-positive cells were counted in the SVZ 6 days after delivery of equal amounts of lentiviral or retroviral vector. Data are expressed relative to the total population of dex-positive cells. Lentiviral vectors are more efficient in transduction of neuronal progenitors. (C) Moreover, over time the proportion of eGFP- and dcx-positive cells in the SVZ increased linearly $\left(r^{2}=\right.$ 0.93 ), which further supports stable long-term transduction in NSCs of the SVZ after lentiviral vector-mediated gene transfer. 
slowly dividing stem cells (type B cells) or migrating neuroblasts (type A cells), brain sections were costained with anti-BrdU and anti-eGFP antibodies together with either anti-GFAP, anti-dcx, or anti-PSA-NCAM antibodies for subsequent analysis by confocal microscopy. In Fig. 4C-E, cells positive for eGFP and GFAP (type B cells); eGFP, doublecortin, and BrdU (type A cells); and eGFP, PSA-NCAM, and BrdU (type A cells) are shown in the SVZ. GFAP is a marker for type B cells and glial cells but GFAPand eGFP-positive cells did not colabel with S-100 $\beta$, a marker for mature glial cells only (data not shown). Because these cells were detected at all time points tested, it implies that transduced stem cells keep generating BrdU-incorporating, eGFP-expressing progenitor cells that migrate to the OB.

\section{Quantification of transduction efficiency in the $O B$ and SVZ}

After lentiviral vector-mediated gene transfer into the SVZ a clear increase over time in the number of eGFP-positive cells in the $\mathrm{OB}$ was revealed by immunohistochemistry (Fig. 3). This increase was confirmed by stereological quantification of transduced cells in the OB (Fig. 5A). Next, we determined the efficiency of transduction of type A neuroblasts by lentiviral and retroviral vectors. Comparable doses of retroviral and lentiviral vectors $(2.6 \times$ $10^{8}$ and $1.4 \times 10^{8}$ RNA equivalents, respectively), both pseudotyped with VSV-G and encoding eGFP under the control of the CMV promoter, were injected into the SVZ of six animals for analysis 6 days later. Dcx-eGFP double immunofluorescence stainings were carried out on serial sections throughout the transduced brain area and double-positive cells were identified by $z$ stack confocal analysis. We counted the dcx- and eGFP-positive cells present in the SVZ, next to the transduced brain area and in the dorsolateral part of the lateral ventricle. In Fig. 5B the number of double-positive cells is shown as a percentage of the total number of dcx-positive cells. Retroviral vectors transduced $7.0 \pm$ $0.8 \%$ whereas lentiviral vectors transduced $11.96 \pm 1.22 \%$ of the dcx-positive cell population (Fig. 5B). Gene transfer into neuroblasts mediated by lentiviral vectors is thus more efficient. Because retroviral vectors transduce only dividing cells, only part of the targeted dcx-positive cells may have been undergoing cell division at the time of vector injection.

Because our results show that the neural stem cell population in the subventricular region (type B cells) is directly targeted by lentiviral vectors, we hypothesized that the continuous division of these cells should result in an increase in labeled progeny over time. Therefore, dcx-eGFP double-positive cells were counted in the SVZ and dorsolateral part of the lateral ventricle at consecutive time points. The number of eGFP- and dcx-positive cells in these regions increased 4-fold, from $7.17 \pm$ $2.04 \%$ at 14 days to $29.21 \pm 8.46 \%$ at 7 months after injection as shown in Fig. 5C (linear correlation, with $r^{2}=0.93$ ). Of note, 6 days after injection, $11.96 \pm 1.22 \%$ of the dcx-positive cells were eGFP positive but at 14 days only $7.17 \pm 2.04 \%$. This small drop in double-labeled cells may be due to direct transduction of migrating dcx-positive cells early after injection.

\section{Morphological characterization of transduced $N P C$ progeny in the $O B$}

Because stable integration of lentiviral and retroviral vectors into the genome of neural stem cells, and/or their progeny, re- sults in stable marker gene expression without the risk of dilution on cell division, we employed this technology for morphological characterization of transduced cells. Moreover, we demonstrated that neuronal stem cell targeting by lentiviral vectors can be used for long-term follow-up of migrating and differentiating NSC/NPC progeny in vivo and we used this advantage to study the morphological characteristics of labeled cells in the $\mathrm{OB}$ for comparison with the morphology described after retroviral transduction.

It was previously reported that retroviral labeling of mitotic cells in the SVZ (Luskin, 1993; Petreanu and Alvarez-Buylla, 2002) highlighted neuroblast migration from the SVZ into the subependymal layer of the OB. This migration takes 2 to 7 days and is followed by 5 to 7 days of radial migration into the overlying granular layer. The subsequent maturation from simple unbranched granular cells (9-13 days) into fully mature neurons with dendritic branches in the external plexiform layer requires 15 to 30 days. In our study, the early detection of eGFPpositive cells in the subependymal layer 2 days after injection and the presence of simple unbranched granular cells at 1 week, followed by the accumulation of fully mature branched granular cells (Fig. 3), are all in accordance with this report. However, it was shown by BrdU and retroviral vector labeling that a large percentage of newly generated cells in the OB are eliminated within a few weeks of birth (Petreanu and AlvarezBuylla, 2002; Winner et al., 2002). After lentiviral vector-mediated stable gene transfer into the SVZ, long-term follow-up of migrating and differentiating cells resulted in an even distribution of marked cells throughout the whole OB (Fig. 6A), but in the granular layer eGFP-expressing cells were often in close contact with each other in small groups of cells (Fig. 6I and K). Most of the marked cells had the typical morphology of granular neurons with a round cell body, a rather thin cytoplasm, and long processes aiming at the external plexiform layer (Fig. 6B, H, and I). Cell bodies were often found close to the neurites from other cells (Fig. 6I). This may suggest that newly arriving cells may be guided by neurites from more mature cells for their migration into the OB. Sometimes cell bodies close to these neurites had a rather elongated shape, and this may concur with more immature migrating cells (Fig. 6I). Interestingly, next to these abundantly present granular cells, less frequently we also found morphologically different cell types in the granular layer with different intensities of eGFP staining, independent of cell type. We found cells with a triangle-shaped cell body (Fig. 6H) and cells with a large cytoplasm and a clearly visible dark nucleus (Fig. 6J). On occasion, fragmented cell bodies were observed in the granular layer, indicative of cells undergoing apoptosis. Rarely, cells with a round cell body and multiple thin neurites attached to the cell body (Fig. 6L) were observed and a few times cells were found in close contact with blood vessels in the granular layer (Fig. 6M). In the more superficial part of the granular layer, cells were present with a wider neurite and clearly visible neuritic spines projecting to the external plexiform layer (Fig. 6J). For the observed morphologies we cannot distinguish between different functionality of the cell and different stages in maturation and cell death. In the glomerular layer (Fig. 6C), cells in the glomeruli were extensively branched as has been described after retroviral vector labeling (Fig. 6E). However, we also detected cells with a few branches (Fig. 6D) next to the external plexiform layer and 


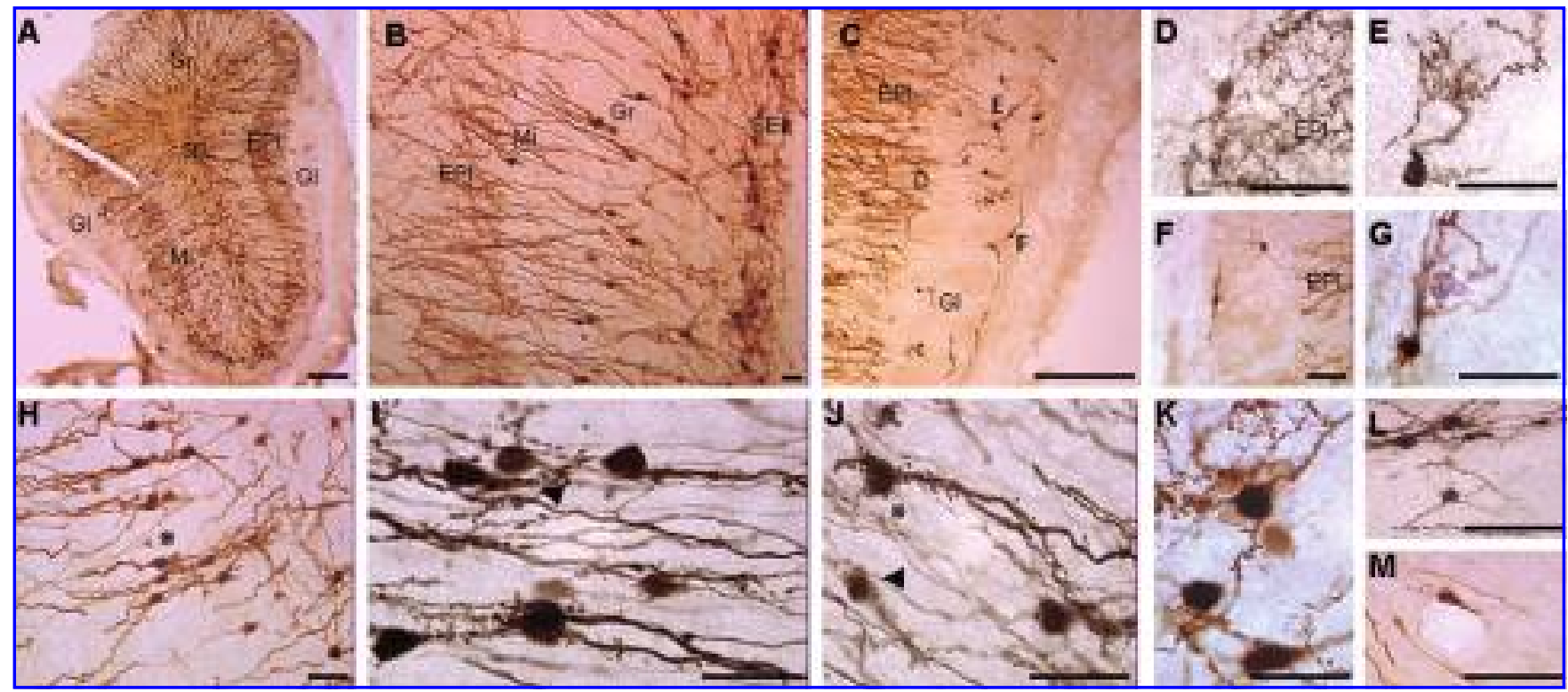

FIG. 6. Morphological evaluation of marked cells in the OB. Shown are coronal sections through the OB, immunostained for eGFP. (A and B) Overview of eGFP-marked cells in the OB layers. (B) is a detailed view of (A). In the glomerular layer $(\mathbf{C})$, next to complex branched cells $[(\mathbf{E})$; note that $(\mathbf{D}),(\mathbf{E})$, and $(\mathbf{F})$ are enlargements of areas marked in $(\mathbf{C})]$, we also detected cells with a few branches next to the external plexiform layer (D) and cells with neurites close to blood vessels of the outer layer of the OB [F; detailed view in $(\mathbf{G})$ ]. ( $\mathbf{H}$ and $\mathbf{I})$ Granular neurons are often detected in clusters $(\mathbf{K})$ and have a round cell body with a rather small cytoplasm and long processes aiming at the external plexiform layer. Cells with an elongated cell body [arrowhead in (I)] or triangular-shaped cell body [asterisk in $(\mathbf{H})$ ] were also detected. (J) Cells with a large cytoplasm and a clearly visible dark nucleus [arrowhead in $(\mathbf{J})$ ] and cells with a wider neurite and clearly visible neuritic spines [asterisk in $(\mathbf{J})$ ] were detected in the more superficial part of the granular layer. (L) Detailed picture of a cell with a round cell body and multiple thin neurites. (M) Rarely, cells were observed in close contact with blood vessels in the granular layer. Scale bars: (A and C) 100 $\mu \mathrm{m}$; all other panels, $10 \mu \mathrm{m}$. EPl, external plexiform layer; Gl, glomerular layer; Gr, granular layer; Mi, mitral cell layer; SEL, subependymal layer.

marked cells were also found close to the most superficial layer (Fig. 6F and $\mathrm{G}$ ) of the $\mathrm{OB}$, with extensions often in close contact with blood vessels (Fig. 6G). They also may make contacts here with projections from olfactory sensory neurons from the nasal neuroepithelium.

\section{Transduction of type B stem cells by injection of lentiviral vectors in the mouse $L V$}

Although some early reports claimed that ependymal cells are the stem cells of the SVZ (Johansson et al., 1999), there is growing evidence that type $B$, astroglial-like cells are the true stem cells of the adult brain (Doetsch et al., 1999a,b; Laywell et al., 2000; Garcia et al., 2004). These type B cells are described as having a uni- or bipolar morphology and a low percentage of these cells in the adult brain have a single cilium that contacts the ventricular lumen (Doetsch et al., 1999b; Garcia et al., 2004). We wondered whether stereotactic delivery of lentiviral vectors into the lateral ventricle could result in transduction of type B cells next to ependymal cells. This delivery route, in contrast to injection into the SVZ, offers the advantage that no postmitotic neurons or glial cells around the needle track are targeted. Therefore, $4.05 \times 10^{6} \mathrm{TU}$ of lentiviral vector in $5 \mu \mathrm{l}$ was injected into the right lateral ventricle of sixteen 8 - to 9-week-old C57BL/6 mice. At 2 days, 2 weeks, 1 month, and 4 months after injection, animals were killed after receiving intraperitoneal injections of $\mathrm{BrdU}(50 \mathrm{mg} / \mathrm{kg})$ for five consecutive days. Because $5 \mu \mathrm{l}$ of highly concentrated vector was injected intraventricularly, three mice were killed 2 days after injection to evaluate toxicity. Brain sections were analyzed microscopically after immunohistochemical staining for eGFP. Injection of lentiviral vector into the lateral ventricle resulted in transduction of ependymal cells throughout the whole ventricular system, from the lateral ventricle to the fourth ventricle. As shown in Fig. 7, most of the eGFP-positive cells (Fig. 7B) present in the LV wall display the typical morphology of multiciliated ependymal cells (type E cells). No apparent toxicity was induced because these cells were detected from 2 days to 4 months after injection. Next to ependymal cells, smaller uni- and bipolar cells (Fig. 7C and D) were detected in the lateral wall of the LV. These cells are described by Garcia et al. (2004) to be type B astroglial-like stem cells. At the base of the lateral ventricle and in the third ventricle, tanycyte-like cells were detected with a long process into the brain parenchyma (Fig. 7E-G). Rarely, eGFP-positive cells were detected near these tanycytes in the parenchyma. Marked cells appeared in the ipsilateral OB starting 2 weeks after injection. From 1 month on, eGFP-positive granular interneurons were also evidenced in the contralateral OB (Fig. 7I). Because injection into the SVZ never resulted in the presence of marked cells in the contralat- 


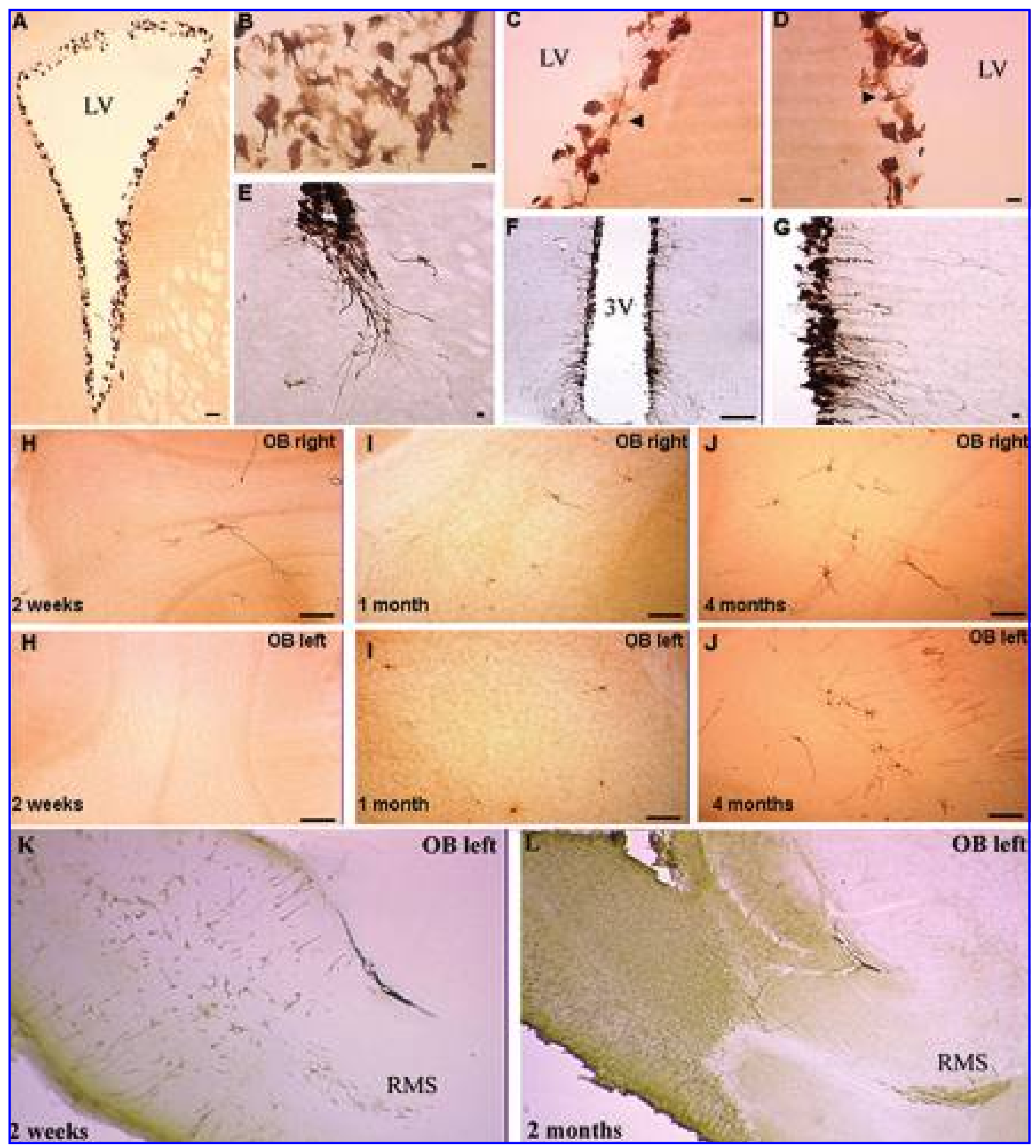

FIG. 7. Gene transfer to ependymal cells and type B stem cells after intraventricular delivery of lentiviral vectors. Immunohistochemical staining of coronal sections for eGFP after intraventricular delivery of lentiviral vectors shows stable long-term gene expression in cells lining the whole ventricular system: overview (A) and higher magnification (B-G) 4 months after injection. Most eGFP-expressing cells in the LV show the typical morphology of multiciliated ependymal cells (B). However, marker gene was also detected in uni- and bipolar cells ( $\mathbf{C}$ and $\mathbf{D}$, arrowheads), with the morphological characteristics of type B stem cells and in tanycyte-like cells at the base of the LV $(\mathbf{E})$ and in the third ventricle $(\mathbf{F}$ and $\mathbf{G})[(\mathbf{G})$ is a higher magnification view of $(\mathbf{F})]$. In the OB, eGFP-positive cells were present at the ipsilateral side $(\mathbf{H}-\mathbf{J})$ starting 2 weeks after injection $(\mathbf{H})$. From 1 month on (I), marker gene expression was present mainly in the granular layer at the ipsilateral and contralateral sides. The number of eGFP-positive cells increased slightly over time as shown in (J) and (M) (4 months). In addition, intraventricular delivery in mice 3 weeks of age ( $\mathbf{K}$ and $\mathbf{L}$ ) resulted in more efficient labeling of the SVZ-RMS-OB system at the ipsilateral and contralateral sides. Moreover, labeled cells in the OB clearly increased over time. Scale bars: $(\mathbf{A}, \mathbf{F}$, and $\mathbf{H}-\mathbf{J}) 100 \mu \mathrm{m} ;(\mathbf{B}-\mathbf{E}$ and G) $10 \mu \mathrm{m}$. 3V, third ventricle; LV, lateral ventricle; OB, olfactory bulb; RMS, rostral migratory stream. 
eral $\mathrm{OB}$, we conclude that intraventricular injection results in labeling of type B cells contacting the LV in the left and right SVZ. Four months after injection, the number of eGFP-positive cells slightly increased (Fig. 7J) and most of the cells were detected in the granular layer. Compared with lentiviral vector injection into the SVZ, only a few eGFP-positive cells were detected in the RMS at all time points evaluated. To further demonstrate the stem cell characteristics of labeled cells after intraventricular injection, we performed injections in six mice (3 weeks old) and killed them 2 weeks and 2 months later. For this experiment younger animals were used, because the number of astrocytes in contact with the ventricle reportedly decreases with increasing age (22 to $16 \%$ of the cells at P15 and P30, respectively; Tramontin et al., 2003). Importantly, at the time point of injection (P21), the organization of the SVZ and ependymal layer is comparable to that in the adult brain (8- to 9-week-old animals) (Tramontin et al., 2003; Spassky et al., 2005). As shown in Fig. $7 \mathrm{~K}$ and L, cell migration to the OB increased clearly over time both at the ipsilateral and contralateral sides. Moreover, the number of cells in the RMS was higher compared with injections into 8- to 9-week-old animals, probably because of more efficient labeling of type B stem cells, which contact the ventricle. This result confirms that the true type B stem cell can be targeted by intraventricular administration of lentiviral vectors.

Confocal analysis showed the presence of eGFP-GFAP double-positive cells negative for S-100 $\beta$, a marker for mature glial cells and ependymal cells, after injection into animals (both 3 weeks and 8-9 weeks of age) at all time points evaluated (Fig. $8 \mathrm{~B}$ and $\mathrm{C}$ ). Moreover, electron microscopy analysis of eGFPmarked cells confirmed transduction of type B astroglial-like stem cells with the typical presence of intermediate filaments (Fig. 8D and E) (Doetsch et al., 1997). EGFP-positive type A cells were also detected in the RMS and SVZ at all time points evaluated by confocal microscopy after eGFP-doublecortin double labeling (Fig. 8A) and by electron microscopy (Fig. 8F and G).

In conclusion, delivery of lentiviral vectors into the LV resulted in transduction of ependymal cells, mature glial cells, tanycyte-like cells, and type B stem cells. The eGFP-positive cells accumulated in the ipsilateral and contralateral $\mathrm{OB}$ over time. The number of eGFP-positive cells in the SVZ-RMS-OB pathway in 8- to 9-week-old animals, however, was much lower than after injection into the SVZ. However, labeling efficiency of the SVZ-RMS-OB pathway increased on intraventricular injection into younger animals (P21), confirming the true stem cell nature of type B cells.

\section{DISCUSSION}

Cell marking of adult neural stem cells in vivo is of considerable interest not only to study migration and differentiation pathways in developing or adult tissue but also for therapeutic applications. In this study we demonstrate that lentiviral vectors outperform retroviral vectors for stable, efficient, and longterm gene transfer into neural stem cells of adult rodents after stereotactic injection into the SVZ and the LV.

To date, in vivo cell marking of dividing cells in the brain is typically done by BrdU administration or retroviral vector injections, often in combination with immunohistochemical anal- ysis of maturing, migrating, and differentiating cells. Both techniques are used to label cells that are dividing at the time of application, but suffer from important disadvantages. For longterm studies, repeated BrdU administration is stressful for rodents, high concentrations can be toxic and incorporated BrdU can be diluted on cell division, whereas retroviral gene transfer has a rather low efficiency and gene expression is sensitive to downregulation. Alternatively, the presence of cell cycle markers such as $\mathrm{Ki}-67$, proliferating cell nuclear antigen (PCNA), and various cyclins indicates the number of dividing cells at a certain time point, although these proteins can be upregulated in pathological CNS conditions through DNA repair and apoptotic pathways. Lentiviral vectors have been proven to be useful tools for gene transfer into nondividing, differentiated cells such as postmitotic neurons (Bukrinsky et al., 1993) and hematopoietic stem cells (Amsellem et al., 2002; TaharaHanaoka et al., 2002; Kurre et al., 2004). Because the NSCs of the SVZ are slowly proliferating astrocyte-like cells (type B cells) (Doetsch et al., 1999a; Garcia et al., 2004; Ahn and Joyner, 2005), this may explain the efficiency with which lentiviral vectors transduce NSCs in the SVZ, in contrast to retroviral vectors (Morshead et al., 1994).

What does our work tell us about adult neural stem cell biology? Previous studies have suggested that SVZ type B astrocyte-like cells behave as self-renewing stem cells (Doetsch et al., 1999a; Laywell et al., 2000; Garcia et al., 2004). These cell surprisingly express GFAP, a marker for mature glial cells, but they are distinguished by their uni- or bipolar morphology (Garcia et al., 2004) and sometimes contact the ventricular lumen (Doetsch et al., 1999b) with a single cilium. Our analysis of the SVZ-RMS-OB pathway at various time points after stereotactic injection of lentiviral vectors in the SVZ revealed stable longterm marker gene expression in cells lining the SVZ and in the RMS, with an accumulation of eGFP-expressing cells in the OB over time. This observation was confirmed by stereological quantification. The increase in transduced neurons in the olfactory bulb can be explained only by a continuous migration and differentiation of cells, originating from the SVZ, that constitutively divide and express eGFP after a single delivery of lentiviral vector. Whereas most of the $\gamma$-aminobutyric acid (GABA)ergic interneurons in the olfactory bulb are generated early after birth, about $2 \%$ are generated during a period ranging from the third postnatal week to adulthood (Bayer, 1983; Mirich et al., 2002; Lemasson et al., 2005). A large proportion of these bulbar interneurons generated in adulthood undergo cell death a few weeks after arrival in the OB (Petreanu and Alvarez-Buylla, 2002; Winner et al., 2002; Lemasson et al., 2005). The exponential increase in eGFP-expressing neurons in the OB, which leveled off at later time points, can be explained by a balance between survival and death of specific cells. In the OB the principal projection neurons, the mitral and tufted cells, are known to originate from the ventricular zone prenatally (Bayer, 1983). In accord, marker gene expression was detected mainly in the granular layer and periglomerular layer. Still, a few positive cells were also detected in the mitral cell layer and/or internal plexiform layer as reported by Luskin (1993) and Petreanu and Alvarez-Buylla (2002), who used retroviral vectors to label dividing cells in the SVZ. Because of stable integration of lentiviral vectors into the genome, marker gene expression will also be present in the progeny. Indeed, cells with distinct morphologies 


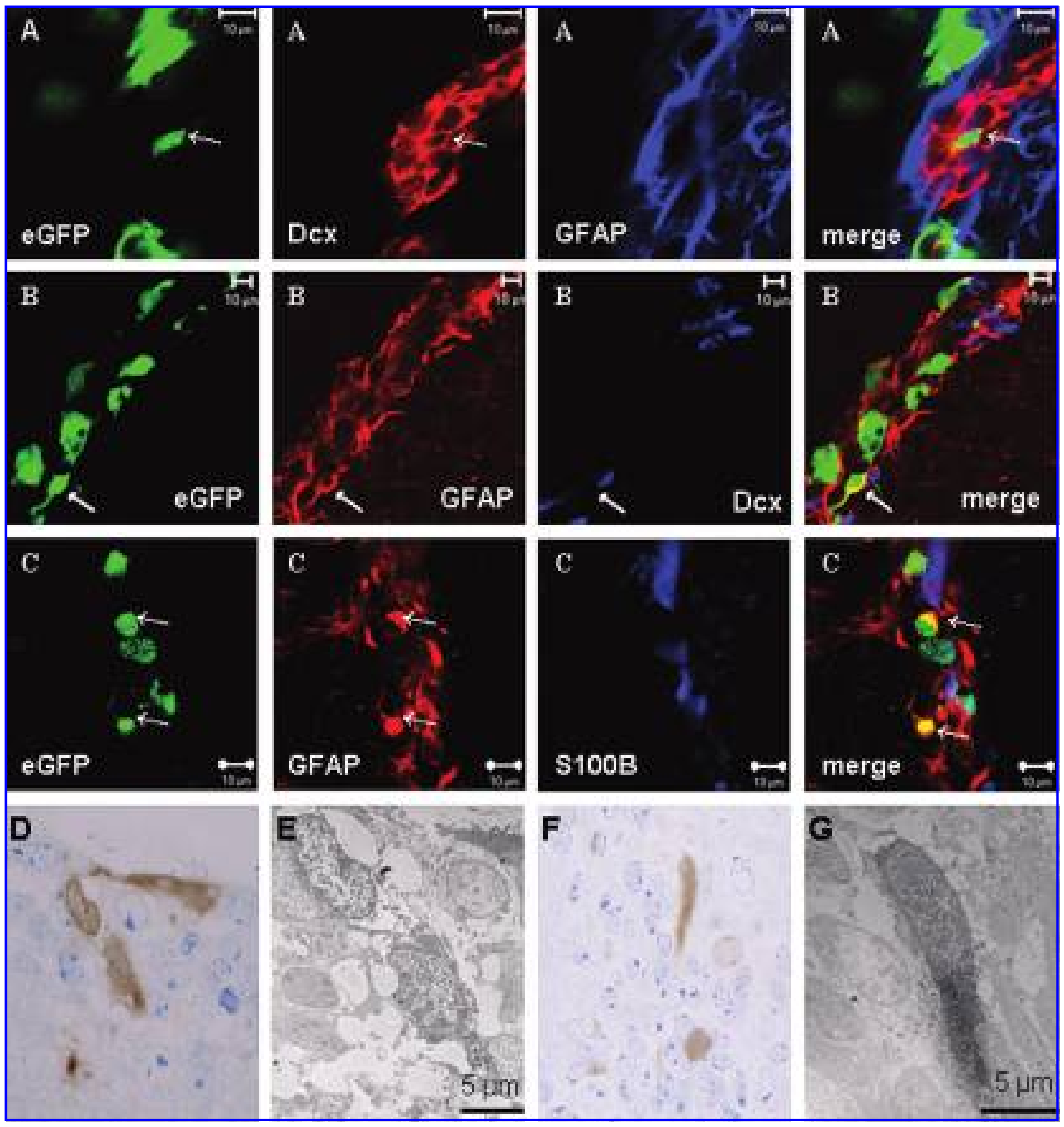

FIG. 8. Characterization of eGFP-expressing cells after lentiviral vector injection into the LV. Triple immunofluorescence staining with anti-eGFP, anti-GFAP, anti-S-100 $\beta$, and anti-dex antibodies and subsequent $z$-stack confocal analysis was performed on coronal OB brain sections from C57BL/6 mice injected via the LV with eGFP-encoding lentiviral vector. Until 4 months after injection, uni- and bipolar cells were detected that colabel with GFAP, a marker for type B astroglial-like stem cells (B) and did not colabel with S-100 $\beta(\mathbf{C})$, a marker for mature glial cells. Moreover, until 4 months after injection, marker gene expression was detected in a few dcx-positive cells, a marker for migrating neurons (A). (D and F) Semithin sections immunostained with eGFP and counterstained with toluidine blue. The same sections were reembedded, cut, and analyzed by EM, revealing type B astroglial-like cells (E) and migratory cells (G).

were detected in the OB. Although the function of these cells has not been studied within this work, we have proven that lentiviral vectors can be used for full morphological characterization of migrating and differentiating cells in the RMS and OB. This should enable future electrophysiological analysis or live imaging to study mechanisms of cell migration, differentiation, and cell-cell interactions.
By colabeling with specific markers, we evidenced lentiviral transduction of migrating neurons or type A cells (doublecortin and PSA-NCAM) in the SVZ. Moreover, some transduced cells in the SVZ were positive for GFAP, a marker for type B astroglial-like stem cells, until 7 months after transduction. In contrast, retroviral vector labeling showed a preferential transduction of rapidly dividing cells instead of slowly di- 
viding type B cells, because migration of retrovirally transduced cells from the SVZ to the OB resulted in progressive loss of eGFP-positive cells in the SVZ. Our results with retroviral vector transduction are in accordance with published results (Luskin, 1993; Petreanu and Alvarez-Buylla, 2002). Lentiviral vectors were more efficient in transducing dcx-expressing cells $(11.96 \pm 1.22 \%)$ than were retroviral vectors $(7.02 \pm 0.8 \%)$, likely because the latter transduce cells only on division. Because type $\mathrm{C}$ cells are rapidly dividing cells, only transduction of type B stem cells can eventually result in continuous labeling of type A cells in the RMS, taking into account that it takes 2 to 7 days for these cells to migrate from the SVZ to the OB. While our work was in progress, Consiglio et al. (2004) reported as well on efficient gene transfer by lentiviral vectors into neuronal stem cells of the SVZ. They subsequently showed that lentiviral vector-transduced eGFP-expressing cells isolated from the SVZ are indeed NSCs because eGFP-positive neurospheres could be formed in vitro. Our data obtained after injection into the SVZ are in agreement with this study.

Importantly, we have now clearly demonstrated a linear increase in dcx-eGFP double-positive cells in the SVZ over time $\left(r^{2}=0.93\right)$. Because dcx-positive cells are generated from rapidly proliferating type $\mathrm{C}$ cells and slowly dividing type $\mathrm{B}$ cells and because newly generated dcx-positive cells continuously migrate to the OB, the increase in eGFP-marked dcx-positive cells over time must be based on stable transduction of type B cells. In addition to the immunohistochemical characterization of eGFP-GFAP double-positive cells in the SVZ, this represents a second proof that true NSCs can be transduced and that transduction did not interfere with cell division and differentiation.

The disadvantage of the currently used lentiviral vectors is the lack of selectivity for NSCs, because postmitotic neurons and glial cells will be transduced equally. This problem might be resolved by improvements in targeting of the lentiviral vectors, either by altering the tropism (e.g., using lymphocytic choriomeningitis virus envelope) (Stein et al., 2005) or by using specific promoters to drive the reporter gene. Alternatively, we reasoned that stereotactic delivery of lentiviral vectors into the ventricle may more selectively transduce type B cells, because only a limited number of type B cells contact the ventricular lumen (Garcia et al., 2004). As expected, intraventricular injection of lentiviral vectors not only resulted in efficient labeling of multiciliated ependymal cells throughout the whole ventricular system, but also of astroglial-like type B cells, as confirmed by confocal and electron microscopy. Because the ependymal layer forms a physical barrier with the underlying SVZ, only cells that contact the ventricle can be transduced. The continuous presence of eGFP-positive cells in the RMS until 4 months, and the accumulation of cells in the ipsilateral and contralateral $\mathrm{OB}$ over time, clearly confirm the transduction of type B cells. Although the number of eGFP-positive cells in the RMS and $\mathrm{OB}$ was much smaller than after delivery into the SVZ, the transduced cell types in the OB appeared identical. In the study by Consiglio et al. (2004), intraventricular injection did not result in labeling of OB neurons. This discrepancy can be explained by the larger volume of lentiviral vector injected in our study ( $5 \mu \mathrm{l}$ instead of $1 \mu \mathrm{l}$ of highly concentrated vector) or by the choice of promoter (CMV versus phosphoglycerate kinase $[\mathrm{PGK}])$. Vector titers, however, are difficult to compare because functional titration is dependent on the cell line and the promoter chosen. In our study, titration was carried out on CHO cells whereas Consiglio et al. used HeLa cells. In addition, we did not find histological evidence of toxicity or LV wall disruption by intraventricular vector delivery. Interestingly, intraventricular delivery of lentiviral vector in young animals (P21) resulted in more robust labeling of the SVZRMS-OB system as compared with injections into 8- to 9week-old animals, probably because of the higher number of type B cells contacting the ventricle at the time of injection (Tramontin et al., 2003).

In conclusion, the long-term presence of eGFP-GFAP and eGFP-doublecortin positive cells in the SVZ and RMS, together with the increasing number of eGFP-positive neurons in the OB over time, prove that stable gene transfer into subventricular NSCs is accomplished by a single lentiviral vector injection in vivo. Our successful gene transfer into NSCs after injection into the lateral ventricle confirms the true stem cell nature of the type B cells that are projecting into the LV wall. Because lentiviral vectors are useful tools for cell marking and gene transfer into adult neural stem cells in vivo, this approach can be used to monitor cell migration, proliferation, and differentiation in various animal models of brain pathology, including neurodegenerative diseases. The gene delivery routes presented here may open therapeutic strategies for CNS disorders, based on stem cell therapy.

\section{ACKNOWLEDGMENTS}

The authors thank the Viral Vector Core (S. Willems, M. Michiels, F. Coun, L. Dekeyzer, I. Thiry, and R. Gijsbers) for outstanding technical assistance, and S. Willems and C. Vallejo for excellent help with histology and stereotactic surgery. The authors gratefully acknowledge Prof. Y. Engelborghs for frequent use of the ConfoCor 2 and J. Vercammen for support with confocal analysis. The HIV-1-derived lentiviral vectors used were derived from constructs kindly provided by $\mathrm{D}$. Trono (University of Geneva, Switzerland), O. Danos (Généthon, Evry, France), and P. Charneau (Institut Pasteur, Paris, France). The retroviral vector constructs used (CMVintron and LNCGFP) were kind gifts of F.L. Cosset (INSERM, Lyon, France) and G. Towers (University College London, UK), respectively. M. Geraerts is funded by a grant from the Institute for Promotion of Innovation through Science and Technology in Flanders (IWT-Vlaanderen). V. Baekelandt is a postdoctoral fellow of the Flemish Fund for Scientific Research (FWO Vlaanderen). This work was funded by SBO grant IWT-30238 from the Flemish Institute supporting scientific-technological research in industry (IWT), by G.0164.03 from the Flemish Fund for Scientific Research (FWO Vlaanderen), and by EC grants QLK3-CT-2002-02114 [(N)EUROPARK] and FP6-project DiMI (LSHB-CT-2005-512146).

\section{REFERENCES}

AHN, S., and JOYNER, A.L. (2005). In vivo analysis of quiescent adult neural stem cells responding to Sonic hedgehog. Nature 437, 894-897. 
ALTMAN, J. (1969). Autoradiographic and histological studies of postnatal neurogenesis. IV. Cell proliferation and migration in the anterior forebrain, with special reference to persisting neurogenesis in the olfactory bulb. J. Comp. Neurol. 137, 433-457.

ALTMAN, J., and DAS, G.D. (1965). Autoradiographic and histological evidence of postnatal hippocampal neurogenesis in rats. J. Comp. Neurol. 124, 319-335.

ALVAREZ-BUYLLA, A., and GARCIA-VERDUGO, J.M. (2002). Neurogenesis in adult subventricular zone. J. Neurosci. 22, 629-634. ALVAREZ-BUYLLA, A., and LIM, D.A. (2004). For the long run: Maintaining germinal niches in the adult brain. Neuron 41, 683-686.

AMSELlEM, S., RAVET, E., FICHELSON, S., PFLUMIO, F., and DUBART-KUPPERSCHMITT, A. (2002). Maximal lentivirus-mediated gene transfer and sustained transgene expression in human hematopoietic primitive cells and their progeny. Mol. Ther. 6, 673-677.

BAEKELANDT, V., CLAEYS, A., EGGERMONT, K., LAUWERS, E., DE STROOPER, B., NUTTIN, B., and DEBYSER, Z. (2002). Characterization of lentiviral vector-mediated gene transfer in adult mouse brain. Hum. Gene Ther. 13, 841-853.

BAEKELANDT, V., EGGERMONT, K., MICHIELS, M., NUTTIN, B., and DEBYSER, Z. (2003). Optimized lentiviral vector production and purification procedure prevents immune response after transduction of mouse brain. Gene Ther. 10, 1933-1940.

BAYER, S.A. (1983). ${ }^{3} \mathrm{H}$-thymidine-radiographic studies of neurogenesis in the rat olfactory bulb. Exp. Brain Res. 50, 329-340.

BIEBL, M., COOPER, C.M., WINKLER, J., and KUHN, H.G. (2000). Analysis of neurogenesis and programmed cell death reveals a selfrenewing capacity in the adult rat brain. Neurosci. Lett. 291, 17-20.

BUKRINSKY, M.I., HAGGERTY, S., DEMPSEY, M.P., SHAROVA, N., ADZHUBEL, A., SPITZ, L., LEWIS, P., GOLDFARB, D., EMERMAN, M., and STEVENSON, M. (1993). A nuclear localization signal within HIV-1 matrix protein that governs infection of non-dividing cells. Nature 365, 666-669.

CAMERON, H.A., WOOLLEY, C.S., McEWEN, B.S., and GOULD, E. (1993). Differentiation of newly born neurons and glia in the dentate gyrus of the adult rat. Neuroscience 56, 337-344.

CONSIGliO, A., GRITTI, A., DOLCETTA, D., FOLlENZI, A., BORDIGNON, C., GAGE, F.H., VESCOVI, A.L., and NALDINI, L. (2004). Robust in vivo gene transfer into adult mammalian neural stem cells by lentiviral vectors. Proc. Natl. Acad. Sci. U.S.A. 101, 14835-14840.

CURTIS, M.A., PENNEY, E.B., PEARSON, A.G., VAN ROONMOM, W.M., BUTTERWORTH, N.J., DRAGUNOW, M., CONNOR, B., and FAULL, R.L. (2003). Increased cell proliferation and neurogenesis in the adult human Huntington's disease brain. Proc. Natl. Acad. Sci. U.S.A. 100, 9023-9027.

DOETSCH, F., GARCIA-VERDUGO, J.M., and ALVAREZBUYLLA, A. (1997). Cellular composition and three-dimensional organization of the subventricular germinal zone in the adult mammalian brain. J. Neurosci. 17, 5046-5061.

DOETSCH, F., CAILLE, I., LIM, D.A., GARCIA-VERDUGO, J.M., and ALVAREZ-BUYLLA, A. (1999a). Subventricular zone astrocytes are neural stem cells in the adult mammalian brain. Cell 97, $703-716$.

DOETSCH, F., GARCIA-VERDUGO, J.M., and ALVAREZBUYLLA, A. (1999b). Regeneration of a germinal layer in the adult mammalian brain. Proc. Natl. Acad. Sci. U.S.A. 96, 11619-11624.

FALLON, J., REID, S., KINYAMU, R., OPOLE, I., OPOLE, R., BARATTA, J., KORC, M., ENDO, T.L., DUONG, A., NGUYEN, G., KARKEHABADHI, M., TWARDZIK, D., PATEL, S., and LOUGHLIN, S. (2000). In vivo induction of massive proliferation, directed migration, and differentiation of neural cells in the adult mammalian brain. Proc. Natl. Acad. Sci. U.S.A. 97, 14686-14691.

FRANCIS, F., KOULAKOFF, A., BOUCHER, D., CHAFEY, P., SCHAAR, B., VINET, M.C., FRIOCOURT, G., MCDONNELL, N., REINER, O., KAHN, A., MCCONNELL, S.K., BERWALD-NET-
TER, Y., DENOULET, P., and CHELLY, J. (1999). Doublecortin is a developmentally regulated, microtubule-associated protein expressed in migrating and differentiating neurons. Neuron 23, 247-256.

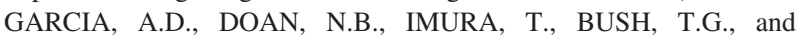
SOFRONIEW, M.V. (2004). GFAP-expressing progenitors are the principal source of constitutive neurogenesis in adult mouse forebrain. Nat. Neurosci. 7, 1233-1241.

GERAERTS, M., MICHIELS, M., BAEKELANDT, V., DEBYSER, Z., and GIJSBERS, R. (2005). Upscaling of lentiviral vector production by tangential flow filtration. J. Gene Med. 7, 1299-1310.

GRITTI, A., BONFANTI, L., DOETSCH, F., CAILLE, I., ALVAREZBUYLLA, A., LIM, D.A., GALLI, R., VERDUGO, J.M., HERRERA, D.G., and VESCOVI, A.L. (2002). Multipotent neural stem cells reside into the rostral extension and olfactory bulb of adult rodents. J. Neurosci. 22, 437-445.

GUILLEMOT, F., and PARRAS, C. (2005). Adult neurogenesis: A tale of two precursors. Nat. Neurosci. 8, 846-848.

HACK, M.A., SAGHATELYAN, A., DE CHEVIGNY, A., PFEIFER, A., ASHERY-PADAN, R., LLEDO, P.M., and GOTZ, M. (2005). Neuronal fate determinants of adult olfactory bulb neurogenesis. Nat. Neurosci. 8, 865-872.

HERRERA, D.G., GARCIA-VERDUGO, J.M., and ALVAREZBUYLLA, A. (1999). Adult-derived neural precursors transplanted into multiple regions in the adult brain. Ann. Neurol. 46, 867-877.

JIN, K., PEEL, A.L., MAO, X.O., XIE, L., COTTRELL, B.A., HENSHALL, D.C., and GREENBERG, D.A. (2004). Increased hippocampal neurogenesis in Alzheimer's disease. Proc. Natl. Acad. Sci. U.S.A. 101, 343-347.

JOHANSSON, C.B., MOMMA, S., CLARKE, D.L., RISLING, M., LENDAHL, U., and FRISEN, J. (1999). Identification of a neural stem cell in the adult mammalian central nervous system. Cell 96, 25-34.

JOHE, K.K., HAZEL, T.G., MULLER, T., DUGICH-DJORDJEVIC, M.M., and McKAY, R.D. (1996). Single factors direct the differentiation of stem cells from the fetal and adult central nervous system. Genes Dev. 10, 3129-3140.

KAPLAN, M.S., and HINDS, J.W. (1977). Neurogenesis in the adult rat: Electron microscopic analysis of light radioautographs. Science 197, 1092-1094.

KEMPERMANN, G., JESSBERGER, S., STEINER, B., and KRONENBERG, G. (2004). Milestones of neuronal development in the adult hippocampus. Trends Neurosci. 27, 447-452.

KURRE, P., ANANDAKUMAR, P., HARKEY, M.A., THOMASSON, B., and KIEM, H.P. (2004). Efficient marking of murine long-term repopulating stem cells targeting unseparated marrow cells at low lentiviral vector particle concentration. Mol. Ther. 9, 914-922.

LAYWELL, E.D., RAKIC, P., KUKEKOV, V.G., HOLLAND, E.C., and STEINDLER, D.A. (2000). Identification of a multipotent astrocytic stem cell in the immature and adult mouse brain. Proc. Natl. Acad. Sci. U.S.A. 97, 13883-13888.

LEMASSON, M., SAGHATELYAN, A., OLIVO-MARIN, J.C., and LLEDO, P.M. (2005). Neonatal and adult neurogenesis provide two distinct populations of newborn neurons to the mouse olfactory bulb. J. Neurosci. 25, 6816-6825.

LIE, D.C., DZIEWCZAPOLSKI, G., WILLHOITE, A.R., KASPAR, B.K., SHULTS, C.W., and GAGE, F.H. (2002). The adult substantia nigra contains progenitor cells with neurogenic potential. J. Neurosci. 22, 6639-6649.

LOIS, C., and ALVAREZ-BUYLLA, A. (1994). Long-distance neuronal migration in the adult mammalian brain. Science 264, 1145-1148.

LOIS, C., GARCIA-VERDUGO, J.M., and ALVAREZ-BUYLLA, A. (1996). Chain migration of neuronal precursors. Science 271, 978-981.

LUSKIN, M.B. (1993). Restricted proliferation and migration of postnatally generated neurons derived from the forebrain subventricular zone. Neuron 11, 173-189. 
MANGANINI, M., SERAFINI, M., BAMBACIONI, F., CASATI, C., ERBA, E., FOLLENZI, A., NALDINI, L., BERNASCONI, S., GAIPA, G., RAMBALDI, A., BIONDI, A., GOLAY, J., and INTRONA, M. (2002). A human immunodeficiency virus type 1 pol gene-derived sequence (cPPT/CTS) increases the efficiency of transduction of human nondividing monocytes and $\mathrm{T}$ lymphocytes by lentiviral vectors. Hum. Gene Ther. 13, 1793-1807.

MARTIN-RENDON, E., WHITE, L.J., OLSEN, A., MITROPHANOUS, K.A., and MAZARAKIS, N.D. (2002). New methods to titrate EIAV-based lentiviral vectors. Mol. Ther. 5, 566-570.

MING, G.L., and SONG, H. (2005). Adult neurogenesis in the mammalian central nervous system. Annu. Rev. Neurosci. 28, 223-250.

MIRICH, J.M., WILLIAMS, N.C., BERLAU, D.J., and BRUNJES, P.C. (2002). Comparative study of aging in the mouse olfactory bulb. J. Comp. Neurol. 454, 361-372.

MORSHEAD, C.M., and VAN DER KOOY, D. (1992). Postmitotic death is the fate of constitutively proliferating cells in the subependymal layer of the adult mouse brain. J. Neurosci. 12, 249-256.

MORSHEAD, C.M., REYNOLDS, B.A., CRAIG, C.G., McBURNEY, M.W., STAINES, W.A., MORASSUTTI, D., WEISS, S., and VAN DER KOOY, D. (1994). Neural stem cells in the adult mammalian forebrain: A relatively quiescent subpopulation of subependymal cells. Neuron 13, 1071-1082.

NALDINI, L., BLÖMER, U., GALLAY, P., ORY, D., MULLIGAN, R., GAGE, F.H., VERMA, I.M., and TRONO, D. (1996). In vivo gene delivery and stable transduction of nondividing cells by a lentiviral vector. Science 272, 263-267.

PALMER, T.D., TAKAHASHI, J., and GAGE, F.H. (1997). The adult rat hippocampus contains primordial neural stem cells. Mol. Cell. Neurosci. 8, 389-404.

PARENT, J.M. (2003). Injury-induced neurogenesis in the adult mammalian brain. Neuroscientist 9, 261-272.

PETREANU, L., and ALVAREZ-BUYLLA, A. (2002). Maturation and death of adult-born olfactory bulb granule neurons: Role of olfaction. J. Neurosci. 22, 6106-6113.

PRICKAERTS, J., KOOPMANS, G., BLOKLAND, A., and SCHEEPENS, A. (2004). Learning and adult neurogenesis: Survival with or without proliferation? Neurobiol. Learn. Mem. 81, 1-11.

REYNOLDS, B.A., and WEISS, S. (1992). Generation of neurons and astrocytes from isolated cells of the adult mammalian central nervous system. Science 255, 1707-1710.

SAGHATELYAN, A., CARLETON, A., LAGIER, S., DE CHEVIGNY, A., and LLEDO, P.M. (2003). Local neurons play key roles in the mammalian olfactory bulb. J. Physiol. Paris 97, 517-528.

SPASSKY, N., MERKLE, F.T., FLAMES, N., TRAMONTIN, A.D., GARCIA-VERDUGO, J.M., and ALVAREZ-BUYLLA, A. (2005). Adult ependymal cells are postmitotic and are derived from radial glial cells during embryogenesis. J. Neurosci. 25, 10-18.

STEIN, C.S., MARTINS, I., and DAVIDSON, B.L. (2005). The lymphocytic choriomeningitis virus envelope glycoprotein targets lentiviral gene transfer vector to neural progenitors in the murine brain. Mol. Ther. 11, 382-389.

TAHARA-HANAOKA, S., SUDO, K., EMA, H., MIYOSHI, H., and NAKAUCHI, H. (2002). Lentiviral vector-mediated transduction of murine CD34- hematopoietic stem cells. Exp. Hematol. 30, 11-17.
TAUPIN, P. (2005). Adult neurogenesis in the mammalian central nervous system: Functionality and potential clinical interest. Med. Sci. Monit. 11, RA247-RA252.

TOWERS, G., COLLINS, M., and TAKEUCHI, Y. (2002). Abrogation of Ref1 retrovirus restriction in human cells. J. Virol. 76, 2548-2550.

TRAMONTIN, A.D., GARCIA-VERDUGO, J.M., LIM, D.A., and ALVAREZ-BUYLLA, A. (2003). Postnatal development of radial glia and the ventricular zone (VZ): A continuum of the neural stem cell compartment. Cereb. Cortex 13, 580-587.

VAN MAELE, B., DE RIJCK, J., DE CLERCQ, E., and DEBYSER, Z. (2003). Impact of the central polypurine tract on the kinetics of human immunodeficiency virus type 1 vector transduction. J. Virol. 77, 4685-4694.

WEST, M.J., SLOMIANKA, L., and GUNDERSEN, H.J. (1991). Unbiased stereological estimation of the total number of neurons in the subdivisions of the rat hippocampus using the optical fractionator. Anat. Rec. 231, 482-497.

WINNER, B., COOPER-KUHN, C.M., AIGNER, R., WINKLER, J., and KUHN, H.G. (2002). Long-term survival and cell death of newly generated neurons in the adult rat olfactory bulb. Eur. J. Neurosci. 16, 1681-1689.

YAMADA, M., ONODERA, M., MIZUNO, Y., and MOCHIZUKI, H. (2004). Neurogenesis in olfactory bulb identified by retroviral labeling in normal and 1-methyl-4-phenyl-1,2,3,6-tetrahydropyridinetreated adult mice. Neuroscience 124, 173-181.

ZHAO, M., MOMMA, S., DELFANI, K., CARLEN, M., CASSIDY, R.M., JOHANSSON, C.B., BRISMAR, H., SHUPLIAKOV, O., FRISEN, J., and JANSON, A.M. (2003). Evidence for neurogenesis in the adult mammalian substantia nigra. Proc. Natl. Acad. Sci. U.S.A. 100, 7925-7930.

ZUFFEREY, R., DULL, T., MANDEL, R.J., BUKOVSKY, A., QUIROZ, D., NALDINI, L., and TRONO, D. (1998). Self-inactivating lentivirus vector for safe and efficient in vivo gene delivery. J. Virol. 72, 9873-9880.

ZUFFEREY, R., DONELlO, J.E., TRONO, D., and HOPE, T.J. (1999). Woodchuck hepatitis virus posttranscriptional regulatory element enhances expression of transgenes delivered by retroviral vectors. J. Virol. 73, 2886-2892.

$$
\begin{array}{r}
\text { Address reprint requests to: } \\
\text { Dr. Zeger Debyser } \\
\text { Laboratory for Molecular Virology and Gene Therapy } \\
\text { Division of Molecular Medicine, } \\
\text { Katholieke Universiteit Leuven } \\
\text { Kapucijnenvoer 33, VCTB }+5 \\
\text { B-3000 Leuven, Belgium }
\end{array}
$$

E-mail: Zeger.Debyser@med.kuleuven.be

Received for publication March 23, 2006; accepted after revision April 14, 2006.

Published online: May 5, 2006. 